\title{
FORMULATING A LOW-ALKALINITY, HIGH-RESISTANCE AND LOW-HEAT CONCRETE FOR RADIOACTIVE WASTE REPOSITORIES
}

Céline CAU DIT COUMES ${ }^{1 *}$, Simone COURTOIS ${ }^{2}$, Didier NECTOUX ${ }^{3}$, Stéphanie LECLERCQ $^{4}$, Xavier BOURBON ${ }^{5}$

${ }^{1}$ Commissariat à l'Energie Atomique, DTCD/SPDE/L2ED, CEN Valrhô, 30207 Bagnols-surCèze cedex, France

${ }^{2}$ Université Aix-Marseille II, Laboratoire EA(MS) ${ }^{2}$, Avenue Gaston Berger, 13625 Aix-enProvence cedex, France

${ }^{3}$ Ecole des Mines d'Alès, Centre des Matériaux de Grande Diffusion, 6 avenue de Clavières, 30319 Alès Cedex, France

${ }^{4}$ EDF, Centre de Recherche des Renardières, BP1 Ecuelles, 77250 Moret-sur-Loing, France

${ }^{5}$ ANDRA, Direction Scientifique / Service Colis-Matériaux, Parc de la Croix Blanche, 1-7 rue Jean Monnet, 92298 Châtenay-Malabry cedex, France

* Corresponding author - e mail address: celine.cau-dit-coumes@cea.fr 


\section{ABSTRACT}

Investigations were carried out in order to formulate and characterize low-alkalinity and lowheat cements which would be compatible with an underground waste repository environment. Several systems comprising Ordinary Portland Cement (OPC), a fast-reacting pozzolan (silica fume (SF) or metakaolin (MK)) and, in some cases, a slow-reacting product (fly ash (FA) or blastfurnace slag (BFS)) were compared. Promising results were obtained with some binary mixtures of OPC and SF, and with some ternary blends of OPC, SF and FA or BFS: pH of water in equilibrium with the fully hydrated cements dropped below 11 . Dependence of the properties of standard mortars on the high contents of FA and SF in the low-pH blends was examined. Combining SF and FA seemed attractive since SF compensated for the low reactivity of FA, while FA allowed to reduce the water demand, and dimensional variations of the mortars. Finally, low-heat $\left(<20^{\circ} \mathrm{C}\right.$ under semi-adiabatic conditions $)$ and high strength $(\approx 70-80 \mathrm{MPa})$ concretes were prepared from two low-pH cements: a binary blend made from $60 \%$ of OPC and $40 \%$ of SF, and a ternary blend including $37.5 \% \mathrm{OPC}, 32.5 \% \mathrm{SF}$ and $30 \%$ FA.

KEYWORDS: A: pH, A: Mixture-proportioning, D: Pozzolan, E: Concrete, E: Radioactive waste 


\section{INTRODUCTION}

\subsection{Framework}

The long-term management of substances produced by nuclear power plants has become a key challenge for society. One of the options is to dispose of medium or high-level and longlived wastes in deep geological structures [1]. Current concepts are based on a multibarrier design approach. The engineered barrier, which could be a clay-based material (especially in the case of high-level and long-lived wastes), would protect the waste packages, postpone the arrival of water and fix radioelements after the decay of the packages containment properties. The geological barrier (host rock), selected for its stability over geological time scales, would prevent intrusion and, in the last resort, isolate any radionuclides that might potentially escape. Furthermore, a modular design could be adopted. This allows different types of packages to be placed in vaults accessed via handling galleries and thus to be separately managed. The packages would be taken down to depths of the order of $500 \mathrm{~m}$ through a system of vertical shafts. Association of concrete and swelling bentonite clay might be used to seal the vaults, as schematically shown in figure 1 . In this context, it has been pointed out that the clay properties may be degraded by the high $\mathrm{pH}$ conditions set by the cement interstitial pore water [2]. Moreover, a high temperature rise caused by cement hydration in massive concrete could induce micro-cracking of the material, with negative consequences on its longterm evolution. Investigations have thus been carried out to formulate and characterize lowalkalinity and low-heat cements which would show an improved compatibility with the repository environment, and which could be used to elaborate high-strength concrete. Table 1 presents the set of criteria which were defined in a first approach.

\subsection{How to formulate a low-pH cement?}




\subsubsection{Calcium silicate cements}

A hardened paste of Ordinary Portland Cement (OPC) is a porous medium composed of solid phases and, for usual water/cement (W/C) ratios and curing conditions, of a liquid phase located in the porosity. The main solid components are portlandite, calcium silicate hydrates and hydrated aluminate phases, their respective proportions being roughly $20 \%, 70 \%$ and $10 \%$. As for pore water, it is a very alkaline solution: typical concentrations after 180 days for pastes of W/C ratio 0.5 are $0.08 \mathrm{~mol} . \mathrm{L}^{-1}$ for $\mathrm{Na}^{+}$and $0.24 \mathrm{~mol} . \mathrm{L}^{-1}$ for $\mathrm{K}^{+}$for a low-alkali cement, and $0.16 \mathrm{mol.} \mathrm{L}^{-1}$ for $\mathrm{Na}^{+}$and $0.55 \mathrm{~mol} . \mathrm{L}^{-1}$ for $\mathrm{K}^{+}$for a high-alkali cement [3-5]. The corresponding $\mathrm{OH}^{-}$concentrations are $0.32 \mathrm{~mol} . \mathrm{L}^{-1}$ and $0.71 \mathrm{~mol} . \mathrm{L}^{-1}$ respectively, and the resulting $\mathrm{pH}$ values above 13 . The pore water chemistry depends on the solubilities of the solid phases in presence. Its evolution during leaching of the cement paste by pure water can be schematically described as follows (figure 2) [6-7]. In a first stage, the pore solution is dominated by highly soluble alkali hydroxides and $\mathrm{pH}$ is above 13 . In a second stage, the pore solution chemistry is controlled by dissolution of calcium hydroxide. The total dissolved calcium is about $20 \mathrm{mmol} / \mathrm{L}$ and $\mathrm{pH}$ is buffered at c.a. 12.5. In a third stage, $\mathrm{C}-\mathrm{S}-\mathrm{H}$ gel and in particular the $\mathrm{C} / \mathrm{S}$ ratio of the gel determines the pore solution chemistry; $\mathrm{pH}$ drops continuously to c.a. 10.8 . This process shows that a low pore water $\mathrm{pH}$ value can be achieved by a strong reduction in the alkali concentration, and an absence of portlandite when hydration is completed. Under these conditions, $\mathrm{pH}$ is controlled by the $\mathrm{C}-\mathrm{S}-\mathrm{H}$ dissolution: the lower the $\mathrm{C} / \mathrm{S}$ ratio, the lower the $\mathrm{pH}$.

To formulate a low-pH cement, adding pozzolanic materials to OPC should be advantageous in at least three respects: $(i)$ portlandite formed by the hydration of OPC is converted into C$\mathrm{S}-\mathrm{H}$ by pozzolanic reaction, (ii) OPC is diluted, and (iii) the C/S ratio of C-S-H is lowered, which enhances their sorption capacity of alkalis and reduces their equilibrium $\mathrm{pH}$ [8-9]. When mixed with OPC, low-CaO fly ash (FA) is effective to reduce the portlandite content 
[10] and heat output during cement hydration [11]. However, even with incorporation rates exceeding $50 \%$, the interstitial solution of the hydrated material is buffered by residual portlandite and $\mathrm{pH}$ remains above 12 [12-14]. Owing to their fineness and chemical composition, silica fume (SF) and metakaolin (MK) are much more reactive, their minimum replacement rate of cement to remove all portlandite ranging from $25 \%$ to $40 \%$ depending on the studies [15-19]. Furthermore, these two additions are known to improve some properties of the cementitious materials: bleeding is limited [20-21], porosity is refined [16-17, 22-25], which in turn reduces permeability and diffusivity [26-29], and increases mechanical strength [30-34]. However, some difficulties might be expected with high contents of SF or MK: bad workability of the grout due to the important water demand of the two compounds $[19,27]$, inhomogeneous dispersion of SF in the grout [35-36], dilatant behaviour of superplasticized pastes containing MK [37], strong autogenous shrinkage resulting from the decreased pore size [38], and significant temperature rise in massive concrete since SF or MK additions of are not reported to reduce notably the heat of hydration [39-41]. Ternary blends consisting of OPC, of a fast reacting pozzolan (SF or MK) and of a slow reacting pozzolan (FA) might offer significant advantages over binary blends: SF or MK would improve the early age performance of concrete with FA continuously refining the properties of the hardened concrete as it matures [42-48].

Design of high strength concretes from blends of OPC and pozzolans with high replacement levels of cement have already been reported. Gray et al. [49] used a blend comprising equiamounts of OPC and SF. Density was increased by including a quartzitic filler. The W/C ratio was kept at a value as high as possible in order to promote hydration of cement without being detrimental to the properties of the hardened product. The cement content was maintained at a low value so as to limit heat output during hydration. Lagerblad [50] adopted similar principles to formulate a concrete, but the silica fume content was reduced. The concrete 
designed by Mihara et al. [51-53] differed by its blend composition, which additionally contained fly ash, its high cement and low water contents. It was thus characterized by a higher temperature rise during hydration, but also by a higher mechanical strength. When immersed under water, the equilibrium $\mathrm{pH}$ of the three concretes was reduced by more than one unity as compared with a probe made from OPC.

\subsubsection{Other types of cements}

Other binders, involving different hydration reactions, do not produce portlandite, and have less alkaline pore solutions. Their potentialities to match the requirements of table 1 were thus reviewed.

- Calcium aluminate cements

The pore water $\mathrm{pH}$ of calcium aluminate cements, ranging from 11.4 to 12.5 , is reduced as compared to OPC [54]. However, direct use of these binders comes up against three difficulties: $(i)$ the pore solution $\mathrm{pH}$ still exceeds the target value ( $\mathrm{pH} 11),(i i)$ a rapid heat evolution during hydration generates major temperature rise [55], and (iii) a conversion process, which involves the transformation of the metastable hydrates $\mathrm{CAH}_{10}$ and $\mathrm{C}_{2} \mathrm{AH}_{8}$ formed below $30^{\circ} \mathrm{C}$ into the higher density hydrates $\mathrm{C}_{3} \mathrm{AH}_{6}$ and $\mathrm{AH}_{3}$ with the liberation of water, results in an increase in porosity and a decrease in strength [56]. Adding a sufficient quantity of pozzolans might be an interesting solution since it has the beneficial effects of reducing heat output due to cement dilution, of decreasing the pore solution $\mathrm{pH}$, and of counteracting the strength loss with time [57-60]. One of the reasons for this latter phenomenon is believed to be the formation of strätlingite $C_{2} \mathrm{ASH}_{8}$ in preference to $\mathrm{C}_{3} \mathrm{AH}_{6}$. Silica also reacts with calcium in solution, inhibiting the formation of $\mathrm{C}_{2} \mathrm{AH}_{8}$ initially, and $\mathrm{C}_{3} \mathrm{AH}_{6}$ after conversion. Investigations have thus been recently undertaken in order to check 
the feasibility to design a low-pH cement from a blend comprising $80 \%$ calcium aluminate cement and $20 \%$ silica fume [61].

- Calcium sulfoaluminate cements

Raw mixes for calcium sulfoaluminate (CSA) clinkers differ from these for OPC in that they contain significant amounts of sulfates. Therefore, the reactions and products are different. The CSA clinker is mainly composed of yeelimite $\left(\mathrm{C}_{4} \mathrm{~A}_{3} \hat{\mathrm{S}}\right)$, belite $\left(\mathrm{C}_{2} \mathrm{~S}\right)$ and an Al-rich ferrite [62]. After cooling, it is interground with gypsum to a fine powder. By increasing the proportion of gypsum (typically from 10 to $25 \%$ ), a series of cements, ranging from rapidhardening to shrinkage-compensating, and eventually to self-stressing, can be produced [63]. CSA cement pastes harden through the formation of an initial ettringite skeleton, and its subsequent infilling by mixtures of ettringite, calcium monosulfoaluminate hydrate, $\mathrm{C}-\mathrm{S}-\mathrm{H}$, alumina and ferrite gel $[64,65]$. The reported pore solution $\mathrm{pH}$ values of CSA mortars are highly variable, ranging from 8.5 to 13 [66-68]. In order to get more accurate data, additional experiments have thus been carried out on cement pastes (W/C 0.4) with increasing gypsum contents (from 0 to $30 \%$ ). The pastes were cured for 90 days in air-tight bag at room temperature before being crushed to a size below $80 \mathrm{~nm}$ and put under water (batch experiments with a liquid/solid ratio of $9 \mathrm{~mL} / \mathrm{g}$ ). Whatever the gypsum content, $\mathrm{pH}$ of the suspensions rapidly reached the equilibrium value of 11.8 , which could indicate of a control of the solution chemistry by ettringite dissolution, and which exceeded the target value expected for low-pH cements. CSA cements were thus discarded in a first approach.

- Phospho-calcic cements

Phospho-calcic cements could seem attractive at first sight. Hydroxyapatite, which is the thermodynamically stable resulting product, has a very low solubility in neutral or basic medium and leads to equilibrium $\mathrm{pH}$ within the range 7-9 [69-74]. However, up to now, very 
few materials have been designed to be workable using contemporary engineering practices, and they all show poor mechanical strength.

- Magnesia phosphate cements

The last cements under consideration were the magnesia phosphate binders, the pore solution $\mathrm{pH}$ of which being typically within the range 7-8 [72]. These cements, which are based on an acid-base reaction between deadburnt magnesia and a phosphate salt [73-77], have however a redhibitory drawback, their very rapid heat release, which precludes their use for massive concrete.

\subsection{Objectives of the work}

It was concluded from the literature review that low-pH and low-heat cement may be obtained by blending OPC, or possibly calcium aluminate cements, with high amounts of artificial pozzolans such as silica fume, metakaolin or low CaO-fly ash. An experimental program was then undertaken at the laboratory scale to supplement the literature data. Emphasis was placed on the design of blends of calcium silicate cements and pozzolans. The objective was to test and compare blends described in the literature, to perform a more systematic investigation of the binary or ternary systems composed of OPC or slag and pozzolans (silica fume, metakaolin, and fly ash) in order to identify alternative formulas, and to check the feasibility to design a low-heat and high strength concrete from the most promising blends.

\section{EXPERIMENTAL}

\subsection{Components of the blends}


Table 3 shows the composition and properties of the components used to design low-pH blends. Three pozzolans were investigated : silica fume, which was used in a densified form for easier handling, commercial metakaolin, and low-CaO fly ash. They were characterized by their pozzolanic index, which represents the amount of portlandite reacting with one gram of pozzolan. SF and MK were much more reactive than FA in the short term, which was due for a part to their high specific area. The two hydraulic compounds (OPC and BFS) were selected for their low alkali content.

\subsection{Blend selection}

In a first step, blends were selected according to the following criterion: $\mathrm{pH}$ of water in equilibrium with hydrated cement should be below 11 . Given the very long time required to get complete hydration of cement under standard curing conditions, a special procedure was developed. Experiments were carried out under nitrogen atmosphere on cement suspensions (W/C ratio of $9 \mathrm{~mL} / \mathrm{g}$ ) under mild milling conditions. Hydrates formed at the surface of the cement grains were eroded, and anhydrous cement was thus maintained in direct contact with water. The suspension $\mathrm{pH}$ was monitored until stabilization. The solid phases were then analyzed using XRD (Siemens D8 - Copper anode $\lambda_{\mathrm{K} \alpha 1}=1.54056 \AA$ A) and TGA (TA-SDT 2960).

\subsection{Design of mortars}

Standard mortars were prepared from cement, water and siliceous sand $(0 / 2 \mathrm{~mm})$. The water/cement and sand/cement ratios were fixed respectively to 0.5 and 3 . Mixing was performed with a standard mortar mixer (European standard EN 196-1) according to the following sequence: (1) introduction of water, (2) addition of the pre-mixed pulverulents while maintaining slow stirring, (3) adjustment of the grout workability with a 
superplasticizer made of polycarboxylic ether (Chryso Fluid Optima 175), and (4) mixing at high speed for $3 \mathrm{~min}$.

Elaborated materials were characterized by measuring various parameters according to standard procedures : bleeding (French standard NF P 18-359), Vicat setting (EN 196-3), heat of hydration (NF P 15-436), compressive strength (EN 196-1), and swelling or shrinkage (NF P 15-433) of prismatic samples $(4 \times 4 \times 16 \mathrm{~cm})$ cured for 1 year at $20^{\circ} \mathrm{C}$ under water, in air or in an air-tight bag. Porosity was characterized using mercury intrusion porosimetry (Micromeritics Autopore III - investigated pressures ranging from 0.8 to 530000 psia). Crystallized phases of the hardened mortars were identified using XRD, and the portlandite content was estimated using TGA.

\subsection{Design of concrete}

Concrete samples included crushed limestone aggregates, the properties of which were determined : density 2.7 , grain size $0 / 4 \mathrm{~mm}$ and $4 / 15 \mathrm{~mm}$, water absorption $1 \%$, Los Angeles coefficient 24, Micro-Deval coefficient 15. They were prepared with a $50 \mathrm{~L}$ mixer according to the following procedure : (1) mixing of the aggregates for $30 \mathrm{~s},(2)$ addition of cement and mixing for 1 min, (3) addition of water and superplasticizer (Chrysofluid Optima 175) and mixing for $2 \mathrm{~min}$, (4) measurement of the concrete workability with the Abrams cone (European standard EN 12350-2), (5) possible adjustment of the water and superplasticizer contents in case of insufficient slump.

Compressive strength was measured on cylindrical $11 \times 22 \mathrm{~cm}$ samples after 28 days of curing under water at $20^{\circ} \mathrm{C}$, as well as on $7 \times 7 \times 28 \mathrm{~cm}$ prismatic samples after 90 days of curing at $20^{\circ} \mathrm{C}$ under water, in air-tight bag, or in air (50\% relative humidity). Dimensional variations of the $7 \times 7 \times 28 \mathrm{~cm}$ samples were also recorded during their whole period of curing (French standard NF P 18-427). 


\section{RESULTS AND DISCUSSION}

\subsection{Blends selection}

\subsubsection{Binary blends}

Binary blends consisting of OPC (40 to $70 \%$ ) and SF or MK (30 to $60 \%$ ) were first investigated (table 4, figure 3). $\mathrm{pH}$ of the suspensions was almost stabilized after 17 days. It decreased when the amount of SF increased. A levelling-off was however observed for SF contents above 50\%. pH values below 11 could be obtained with blends containing at least $40 \%$ SF. As for MK, the equilibrium $\mathrm{pH}$ remained above 12 whatever the replacement level of OPC.

\subsubsection{Ternary blends}

The combination of a fast reacting pozzolan such as SF or MK and of a slow reacting compound such as fly ash or slag could result in a number of synergistic effects [43, 46-47]. Potentialities of ternary blends were thus studied using experimental designs.

The factors were the fractions of OPC $\left(\mathrm{X}_{1}\right), \mathrm{SF}$ or MK $\left(\mathrm{X}_{2}\right)$, and FA or BFS $\left(\mathrm{X}_{3}\right)$ in the blend. They checked eq. (1), which was characteristic of a three-component mixture problem.

$\mathrm{x}_{1}+\mathrm{x}_{2}+\mathrm{x}_{3}=1$

The factors were constrained between a lower limit $a_{i}$ and an upper limit $b_{i}\left(0<a_{i}<x_{i}<b_{i}<\right.$ 1), which were selected by taking into account data from the literature and results of exploratory trials performed with extreme compositions. The resulting region of interest was a simplex, as shown in figure 4. Response surface methodology is based on the hypothesis that the responses (i.e. $\mathrm{pH}$ of the suspensions) can be approximated, within the range of the data, by a low order polynomial model. The postulated model was thus a special cubic polynomial in the canonical form. 
$y=\beta_{1} x_{1}+\beta_{2} x_{2}+\beta_{3} x_{3}+\beta_{12} x_{1} x_{2}+\beta_{13} x_{1} x_{3}+\beta_{23} x_{2} x_{3}+\beta_{123} x_{1} x_{2} x_{3}$

where $\mathrm{y}=$ response, $\beta_{\mathrm{i}}=$ model parameter to be estimated

The positioning of experimental points within the experimental domain is of great importance to obtain a good precision on the estimates of the model parameters and, in a second step, on model-predicted response values. The well-known simplex-lattice design introduced by Scheffé [78] was used in order to estimate the 7 parameters of the model defined by eq. (2). It included the 3 vertices of the simplex, the 4 edge centroids, and the overall centroid. Three validation points corresponding to mixtures regularly distributed in the investigated domain and as remote as possible from the other selected points were added, for a total of 10 runs (figure 4). Experimental data are summarized in table 5. Two replicates of the overall centroid provided a measure of the experimental error. For each response, the model coefficients were estimated by standard least squares regression techniques (table 6). Possible model deficiencies were looked for by using analysis of variance (ANOVA). The models provided a good correlation of the experimental data for all the investigated responses and were thus regarded as acceptable prediction tools.

From the response contour plots (figure 5), it can be seen that, after 17 days of hydration, $\mathrm{pH}$ of the suspensions made from OPC/SF/FA or OPC/SF/BFS blends mainly depended on the SF content : the higher the SF fraction, the lower the $\mathrm{pH}$. Then, a curvature of the plots was noticeable, which indicated that FA or BFS had also begun to react. When equilibrium was reached (at $73 \mathrm{~d}$ or $112 \mathrm{~d}$ ), all blends checking eq. (3) or (4) led to pH below 11.

\section{OPC / SF / FA blends:}

$19.685 \mathrm{x}_{1}+15.504 \mathrm{x}_{2}+14.346 \mathrm{x}_{3}-26.836 \mathrm{x}_{1} \mathrm{x}_{2}-19.146 \mathrm{x}_{1} \mathrm{x}_{3}-12.774 \mathrm{x}_{2} \mathrm{x}_{3}+24.849 \mathrm{x}_{1} \mathrm{x}_{2} \mathrm{x}_{3}$

$\leq 11$

\section{OPC / SF / BFS blends:}


$19.547 \mathrm{x}_{1}+20.415 \mathrm{x}_{2}+15.861 \mathrm{x}_{3}-53.538 \mathrm{x}_{1} \mathrm{x}_{2}-19.392 \mathrm{x}_{1} \mathrm{x}_{3}-40.000 \mathrm{x}_{2} \mathrm{x}_{3}+125.579 \mathrm{x}_{1} \mathrm{x}_{2} \mathrm{x}_{3}$

$\leq 11$

OPC / MK / FA blends did not allow to meet the requirement of an equilibrium $\mathrm{pH}$ below 11: this latter always remained above 11.5 . On the contrary, the binders comprising $37.5 \%$ OPC, $32.5 \% \mathrm{SF}$ and $30 \% \mathrm{FA}$ or BFS were selected for further experiment. Indeed, among all blends leading to $\mathrm{pH}$ below 11, they had (i) limited SF content, which should reduce water demand, plastic shrinkage and material cost, as well as (ii) a significant OPC content, which should provide high mechanical strength.

\subsubsection{Discussion}

Equilibrium $\mathrm{pH}$ was shown to depend mostly on the silica content of the binders whatever its origin (figure 6). $\mathrm{pH}$ below 11 were obtained for silica contents higher than $\approx 50 \%$, which was only checked by some of the OPC/SF, OPC/SF/FA, and OPC/SF/BFS blends.

XRD analysis performed on the solid fractions at the end of the experiments confirmed that the blends were almost fully hydrated since the anhydrous cement phases were not detected anymore, and that portlandite had been totally depleted by pozzolanic reaction. The absence of afwillite $\left(\mathrm{C}_{3} \mathrm{~S}_{2} \mathrm{H}_{3}\right)$ was also checked. This phase, which can be prepared from $\mathrm{C}_{3} \mathrm{~S}$ by ballmilling with water, and which appears to be thermodynamically stable at ordinary temperature and pressure in the presence of lime and water [79], shows no similarities to C-S-H gel, and nothing resembling it can be obtained in cement pastes cured under usual conditions. Cristallinity of the samples was very low, the most intense peaks in the XRD patterns corresponding to non reactive phases brought by the pozzolanic compounds (quartz, mullite, hematite, and anatase), or to calcite that might have resulted from the carbonation of the samples during filtration and drying. Some hydrated phases were also detected: ettringite 
(traces), strätlingite in samples containing metakaolin, and hydrotalcite in samples containing BFS. The chemistry of the low-pH cements will be the subject of a subsequent article.

\subsection{Elaboration and characterization of mortars}

Mortar samples were elaborated using the selected ternary blend containing silica fume and fly ash. Their properties were compared to a probe made from OPC only, and to low-pH materials described in the literature [49-51] (figure 7, table 7).

\subsubsection{Properties of fresh grouts}

Viscosity of the mortars after mixing strongly increased with their silica fume content, which was counteracted by adding increasing amounts of superplasticizer. The relationship between the superplasticizer content and the silica fume content could be well described by a secondorder polynomial (figure 8). Setting time occurred in less than $8 \mathrm{~h}$ for all samples. It was however slightly retarded for blends containing fly ash, the delay increasing with the FA content. This resulted from the cement dilution and from the low reactivity of fly ash at early age. The heat release during hydration was monitored using semi-adiabatic calorimetry. It decreased with the OPC content. The temperature rise was reduced by a factor 1.33 for the blend with the highest cement replacement level.

\subsubsection{Properties of hardened mortars}

Porosity was characterized after 3, 6 and 12 months of curing under water at ambient temperature. Whatever the age of the samples, adding pozzolanic compounds resulted in an increase in the total porosity, which was maximum for mortar \#3 with the highest FA content. Porosity of 1-year old blended mortars was however refined as compared to the probe. The fraction (y) of pores with a diameter below $20 \mathrm{~nm}$ (related to the C-S-H gel) increased almost 
linearly with the SF content (x) (fitting function: $y=0.8123 x+40.161-r^{2}=0.993$ ). It was also checked that the porosity of the blended mortars decreased with time all the more rapidly since the SF content was high, which once again resulted from the fact that SF was more reactive than FA.

Whatever the type of curing, the dimensional instability of $4 \times 4 \times 16 \mathrm{~cm}$ specimens increased with their SF content (figure 9). The shrinkage increase might have been a consequence of the porosity refinement. Indeed, empty porosity was created within the capillary pore system of the mortars microstructure due to water depletion by cement hydration and desiccation. Largest pores emptied first, followed by pores of decreasing diameter. The water/air menisci created in the partly empty pores induced shrinkage, the magnitude of which depended on the diameter of the pores being emptied: the lower the pore diameter, the higher the stress.

Compressive strength of the specimens depended on the type of curing: the best values were logically achieved for samples cured under water, which thus had the highest degrees of hydration (figure 10). On the contrary, desiccation induced a strength reduction by a factor as high as 1.5. SF had three beneficial effects: it accelerated the hydration of OPC, it converted portlandite into $\mathrm{C}-\mathrm{S}-\mathrm{H}$ by pozzolanic reaction, and it densified the interfacial zone between cement pastes and aggregates. Thus, increasing the SF content of the blends resulted in a rapid hardening and in high compressive strength. On the contrary, the strength gain of FAcontaining mortars \#1 and \#3 was slower and one-year old samples remained less resistant than the probe.

With no measurable portlandite present after respectively 6 and 3 months, $\mathrm{pH}$ values of mortars \#1 and \#2 were significantly lower than that of the reference. However, they remained higher than that obtained in the first section with an accelerated hydration procedure. This discrepancy might be attributed to the fact that hydration of the mortars was 
not complete after one year: $\mathrm{C}_{3} \mathrm{~S}$ and $\mathrm{C}_{2} \mathrm{~S}$ peaks were still observed in the XRD patterns, together with ettringite, quartz and mullite (for mortar \#1 only).

Blend \#1 comprising 37.5\% OPC, 32.5\% SF and 30\% FA seemed to constitute a good compromise between SF-rich (blend \#2) and FA-rich (blend \#3) formulas. SF compensated for low early strength of FA materials and allowed a total depletion of portlandite after 6 months of curing. As for FA, it limited the increased water demand of SF as well as the dimensional instability of the specimens.

\subsection{Concrete mixture-proportioning}

The next step was to design concrete from two low-pH binders: binary blend \#2' made from $60 \%$ OPC and $40 \%$ SF (the minimum SF content to get a pH below 11 under the experimental conditions of section 3.1), and ternary blend \#1 comprising 37.5\% OPC, 32.5\% SF and 30\% FA. The desired properties were as follows: $(i)$ the concrete should be workable, with a slump within the range 100-150 mm, (ii) the temperature rise under semi-adiabatic conditions should be below $20^{\circ} \mathrm{C}$, and (iii) the compressive strength after 90 days of curing under water should exceed $70 \mathrm{MPa}$.

Mixture-proportioning was performed using the conventional Dreux's method [80]. After the production of trials batch, minor adjustments on the plasticizer and water contents were carried out to obtain the required rheological properties, producing the actual recipes given in table 8 . The mix compositions proved to be satisfactory: it was possible, by simple means, to prepare workable concrete despite the very high amounts of pozzolans in the blends. Concrete made with blend \#2' matched all the requirements. As for concrete made with blend \#1, its low heat output should allow to increase the cement content of the recipe, which in turn should improve the mechanical strength of the samples. 


\section{CONCLUSION}

The work presented in this article aimed at designing a low-heat, low-alkalinity and high strength concrete which would be chemically compatible with clay materials in a deep geological repository for nuclear wastes. The main conclusions can be summarized as follows.

1. Low-pH cements can be designed from binary blends of OPC and SF containing at least $40 \% \mathrm{SF}$, or from ternary blends of OPC, SF and FA or BFS. A range of compositions was shown to lead to $\mathrm{pH}$ values below 11 for water in equilibrium with the fully hydrated blends.

2. Rising the silica fume content in the blends allowed to improve some properties of standard mortars elaborated with the low-pH cements: (i) it induced rapid hardening and high compressive strength, (ii) the porosity was refined, although the total porosity remained higher than that of a probe made from OPC, (iii) portlandite formed by OPC hydration was rapidly depleted. However, it also resulted in a bad workability of the grout, which had to be counteracted by adding increasing amounts of superplasticizer, and in a decrease in the dimensional stability of specimens cured under water, in air, or in an air-tight bag. Introducing FA to the blends allowed to decrease the viscosity of the grout and to improve the dimensional stability. However, hardening was slowed down, as well as portlandite consumption. A good compromise was obtained by combining SF and FA in a blend comprising $37.5 \%$ OPC, $32.5 \%$ SF and $30 \%$ FA.

3. Workable, low-heat and high strength concretes could be prepared from two low-pH cements (blend \#1: 37.5\% OPC, 32.5\% SF and 30\% FA, blend \#2': 60\% OPC, 40\% SF) using conventional engineering practices despite the very high amounts of pozzolans in the blends. 


\section{ACKNOWLEDGEMENTS}

M. Sorgenti and H. Juhan from CEA, as well as P. Devillers from EMA-CMGD are deeply acknowledged for their contribution to the experimental work. 


\section{REFERENCES}

[1] ANDRA, 2005 Clay Report- Evaluating the Feasibility of a Geological Repository in Clay Formation, ISBN 2-951-0108-8-5 (2005) 238 p

[2] P. Sellin, F. Karlsson, L. Werme, K. Spahiu, I. Puigdomenech, Effect of pH on the Safety of KBS-3 Deep Repository and the Confidence in the Safety Assessments, Proc. Workshop on Qualification of Low-pH Cement for a Geological Repository, Stockholm, Sweden, October $15-16(2003)$

[3] P. Longuet, L. Burglen, A. Zelwer, The Liquid Phase of Hydrated Cement, Rev. Mater. Constr. (France) 676 (1973) 35-41

[4] H.F.W. Taylor, A Method for Prediciting Alkali Ion Concentrations in Cement Pore Solutions, Adv. Cem. Res. 1 (1987) 5-16

[5] H.J.H Brouwers, R.J. van Eijk, Alkali Concentrations of Pore Solution in Hydrating OPC, Cem. Concr. Res. 33 (2003) 191-196

[6] U.R. Berner, Evolution of Pore Water Chemistry During Degradation of Cement in a Radioactive Waste Repository Environment, Waste Management 12 (1992) 201-219

[7] M. Snellman, T. Vieno, Long-Term Safety Aspects of the Use of Cement in a Repository for Spent Fuel, Proc. $2^{\text {nd }}$ Low pH Workshop, June 15-16, Madrid, Spain (2005) 27-40

[8] P.L. Rayment, The Effect of Pulverized Fuel Ash on the C/S Molar Ratio of Alkali Content of Calcium Silicate Hydrates in Cement, Cem. Concr. Res. 12[2] (1982) 133-140

[9] S.Y. Hong, F.P. Glasser, Alkali Binding in Cement Pastes - Part I - The C-S-H Phase, Cem. Concr. Res. 29 (1999) 1893-1903

[10] H.F.W. Taylor, K. Mohan, G.K. Moir, Analytical Study of Pure and Extended Portland Cement Pastes. II. Fly Ash and Slag Cement Pastes, J. Amer. Ceram. Soc. 68[12] (1985) 685690 
[11] V.M. Malhotra, P.K. Mehta, High Performance, High Volume Fly Ash Concrete: Materials, Mixture Proportioning, Properties, Construction Practice, and Case Histories, Marquardt Printing Ltd, Ottawa, Canada (2002)

[12] M.H. Shehata, M.D.A. Thomas, R.F. Bleszinski, The Effects of Fly Ash Composition on the Chemistry of Pore Solution in Hydrated Cement Pastes, Cem. Concr. Res. 29 (1999) $1915-1920$

[13] K. Torii, K. Taniguchi, M. Kawamura, Sulfate Resistance of High Fly Ash Content Concrete, Cem. Concr. Res. 25[4] (1995) 759-768

[14] V.G. Papadakis, Effect of Fly Ash on Portland Cement Systems - Part I - Low Calcium Fly Ash, Cem. Concr. Res. 19 (1999) 1915-1920

[15] A. Traetteberg, Silica Fume as a Pozzolanic Material, Il Cimento 75[3] (1978) 369-375

[16] C.Y. Huang, R.F. Feldman, Influence of Silica Fume on the Microstructural Development in Cement Mortars, Cem. Concr. Res. 15[2] (1985) 285-294

[17] C.Y. Huang, R.F. Feldman, Hydration Reactions in Portland Cement - Silica Fume Blends, Cem. Concr. Res. 15[4] 585-592

[18] J.A. Kostuch, G.V. Walters, T.R. Jones, Proc. Int. Conf. Concrete 2000, University of Dundee, Scotland 2 (1993) 1799

[19] M. Oriol, J. Pera, Pozzolanic Activity of Metakaolin under Microwave Treatment, Cem. Concr. Res. 25[2] (1995) 265-270

[20] V. Yogendran, B.W. Langan, M.N. Haque, M.A. Ward, Silica Fume in High Strength Concrete, ACI Materials Journal, March-April (1987) 124-129

[21] R. Duval, E.H. Kadri, Influence of Silica Fume on the Workability and the Compressive Strength of High Performance Concretes, Cem. Concr. Res. 28[4] (1998) 533-547 
[22] R.D. Hooton, Influence of Silica Fume Replacement of Cement on Physical Properties and Resistance to Sulfate Attack, Freezing and Thawing, and Alkali-Silica Reactivity, ACI Materials Journal 89[4] (1992) 337-344

[23] A. Durekovic, Cements Pastes of Low Water to Solid ratio: an Investigation of the Porosity Characteristics under the Influence of a Superplasticizer and Silica Fume, Cem. Concr. Res. 25[2] (1995) 365-375

[24] M. Frias, J. Cabrera, Pore Size Distribution and Degree of Hydration of MetakaolinCement Pastes, Cem. Concr. Res. 30 (2000) 561-569

[25] C.S. Poon, L. Lam, S.C. Kou, Y.L. Wong, R. Wong, Rate of Pozzolanic Reaction of Metakaolin in High Performance Cement Pastes, Cem. Concr. Res. 31 (2001) 1301-1306 [26] E.G. Nawy, Fundamentals of High Performance Concrete, $2^{\text {nd }}$ Edition, Wiley, New York (2001) 61-66

[27] K.H. Khayat, P.C. Aitcin, Silica Fume in Concrete, an Overview, in Fly Ash, Silica Fume, Slag and Natural Pozzolans in Concrete, Ed. V.M. Malhotra, ACI SP-132, Detroit, Michigan 2 (1992) 835-872

[28] D.P. Bentz, O.M. Jensen, A.M. Coats, F.P. Glasser, Influence of Silica Fume on Diffusivity in Cement-Based Materials - I - Experimental and Computer Modelling Studies on Cement Pastes, Cem. Concr. Res. 30 (2000) 953-962

[29] B.H. Oh, S.W. Cha, B.S. Jang, S.Y. Jang, Development of High Performance Concrete Having High Resistance to Chloride Penetration, Nuclear Engineering and Design 212 (2002) $221-231$

[30] J.P. Ollivier, A. Carles-Gibergues, B. Hanna, Activité Pouzzolanique et Action de Remplissage d'une Fumée de Silice dans les Matrices de Béton de Haute Résistance, Cem. Concr. Res. 18-3 (1988) 438-448 
[31] E.J. Sellevold, F.F. Radjy, Condensed Silica Fume (Microsilica) in Concrete: Water Demand and Strength Development, in the Use of Fly Ash, Silica Fume, Slag and Natural Pozzolans in Concrete, Ed. V.M. Malhotra, ACI SP-79, Detroit, Michigan 2 (1983) 677-694

[32] D.P. Bentz, P.E. Stutzman, E.J. Garboczi, Experimental and Simulation Studies of the Interfacial Zone in Concrete, Cem. Concr. Res. 22[5] (1992) 891-902

[33] M.D. Cohen, A. Goldman, W.F. Chen, The Role of Silica Gel in Mortar: Transition Zone versus Bulk Paste Modification, Cem. Concr. Res. 24[1] (1994) 95-98

[34] S. Wild, J.M. Khatib, A. Jones, Relative Strength, Pozzolanic Activity and Cement Hydration in Superplasticized Metakaolin Concrete, Cem. Concr. Res. 25[8] 1713-1725

[35] M.I. Sanchez de Rojas, J. Rivera, M. Frias, Influence of the Microsilica State on Pozzolanic Reaction Rate, Cem. Concr. Res. 29 (1999) 945-949

[36] D.R.G Mitchell, I. Hinczak, R.A. Day, Interaction of Silica Fume with Calcium Hydroxide Solutions and Hydrated Cement Pastes, Cem. Concr. Res. 28[11] (1998) 15711584

[37] F. Curcio, B.A. De Angelis, Dilatant Behaviour of Superplasticized Cement Pastes Containing Metakaolin, Cem. Concr. Res. 25[5] 629-634

[38] F. De Larrard, P. Acker, Déformations Libres des Bétons à Hautes Performances, in Les Bétons à Hautes Performances, Caractérisation, Durabilité, Applications, Y. Malier Ed., Presses de l'Ecole Nationale des Ponts et Chaussées, Paris (1992) 157-163

[39] E.H. Kadri, R. Duval, Effect of Ultrafine Particles on Heat of Hydration of Cement Mortars, ACI Materials Journal, march/april (2002) 138-142

[40] J. Ambroise, S. Maximilien, J. Pera, Properties of Metakaolin Blended Cements, Adv. Cem. Based Mat. 1[4] (1994) 161-168

[41] M.H. Zhang, V.M. Malhotra, Characteristics of a Thermally Activated Alumino-Silicate Pozzolanic Material and its Use in Concrete, Cem. Concr. Res. 25[8] (1995) 1713-1725 
[42] W.H. Huang, Properties of Cement - Fly Ash Grout Admixed with Bentonite, Silica Fume or Organic Fibers, Cem. Concr. Res. 27[3] (1997) 395-406

[43] P.K. Mehta, O.E. Gjorv, Properties of Portland Cement Concrete Containing Fly Ash and Condensed Silica Fume, Cem. Concr. Res. (1982) 587-595

[44] V. Lilkov, V. Stoitchkov, Effect of the Pozzolit Active Mineral Admixture on the Properties of Cement Mortars and Concretes - Part 2 - Pozzolanic Activity, Cem. Concr. Res. 26[7] (1996) 1073-1081

[45] C.S. Poon, L. Lam, Y.L. Wong, Effects of Fly Ash and Silica Fume on Interfacial Porosity of Concrete, Journ. Mater. In Civil Engineering, august (1999) 197-205

[46] M.D.A Thomas, M.H. Shehata, S.G. Shashiprakash, D.S. Hopkins, K. Cail, Use of Ternary Cementitious Systems Containing Silica Fume and Fly Ash in Concrete, Cem. Concr. Res. 29 (1999) 1207-1214

[47] L. Lam, Y.L. Wong, C.S. Poon, Effect of Fly Ash and Silica Fume on Compressive and Fracture Behaviours of Concrete, Cem. Concr. Res. 28[2] (1998) 271-283

[48] M.H. Shehata, M.D.A Thomas, Ternary Blends Containing Silica Fume and Fly Ash to Suppress Expansion due to Alkali-Silica Reaction in Concrete, Cem. Concr. Res. 32 (2002) 341-349

[49] M.N. Gray, B.S. Shenton, For Better Concrete, Take out Some of the Cement, Proc. $6^{\text {th }}$ ACI/CANMET Symposium on the Durability of Concrete, Bangkok, Thailand, May 31 June 5 (1998)

[50] B. Lagerblad, High Performing Concrete with Low $\mathrm{pH}$ as Bore Hole Plugging Material, SKB Seminar on Bore Hole Plugging, Aspö, Sweden, February 27 (2003)

[51] K. Iriya, A. Masui, M. Mihara, Study on Applicability of HFSC for Radioactive Waste Repositories, Radioactive Waste Management and Environmental Remediation, ASME Conference, Nagoya, Japan, September 26-30 (1999) 
[52] H. Owada, M. Mihara, T. Mine, A. Neyama, K. Iriya, T. Arimoto, The Geochemical Modeling Study on Leaching Behaviour of HFSC for Cementitious Radioactive Waste Disposal, Radioactive Waste Management and Environmental Remediation, ASME Conference, Nagoya, Japan, September 26-30 (1999)

[53] C. Galle, M. Mihara, H. Peycelon, H. Owada, P. Le Bescop, C. Mazoin, About the Use of Cement-Based Materials for Radioactive Waste Management : a Comparative Study of OPC, BFS-PFA and HFSC Cement Pastes Leaching Behaviour, 5th International Symposium on Cement and Concrete (5th ISCC), Shanghai, China, October 28 - November 1 (2002)

[54] S. Goni, C. Andrade, C.L. Page, Corrosion Behaviour of Steel in High Alumina Cement Mortar Samples : Effect of Chloride, Cem. Concr. Res. 21[4] (1991) 635-646

[55] C.M. George, Industrial Aluminous Cements, in Structure and Performance of Cements, P. Barnes Ed., Applied Science Publishers, London (1983) p 422

[56] A. Capmas, T. Dumas, J.P. Letourneux, Durabilité Spécifique des Bétons de Ciment Alumineux, in La Durabilité des Bétons, J. Baron and J.P. Ollivier Ed., Presses de l'Ecole Nationale des Ponts et Chaussées, Paris (1992) 429-453

[57] A.J. Majumdar, B. Singh, Properties of some Blended High Alumina Cements, Cem. Concr. Res. 22 (1992) 1101-1114

[58] J. Ding, Y. Fu, J.J. Beaudouin, Strätlingite Formation in High Alumina Cement / Silica Fume Systems : Significance of Sodium Ions, Cem. Concr. Res. 25 (1995) 1311-1319

[59] J. Ding, Y. Fu, J.J. Beaudouin, Strätlingite Formation in High Alumina Cement / Zeolite Systems, Adv. Cem. Res. 7 (1995) 171-178

[60] J. Ding, Y. Fu, J.J. Beaudouin, Effect of Different Zeolites on Conversion Prevention in High Alumina Cement Products, ACI Mat. Journ. 94[3] (1997) 220-226

[61] A. Hidalgo, I Llorente, C. Andrade, Preliminary Physico-Chemical Characterization of Some Low pH Concretes Using Silica Fume and Aluminous Cement, Proc. Workshop on 
Qualification of Low pH Cement for a Geological Repository, Stockholm, Sweden October $15-16(2003)$

[62] O. Andac, F.P. Glasser, Microstructure and Microchemistry of Calcium Sulfoaluminate Cement, Mat. Res. Soc. Symp. Proc., 370 (1995) 135-142

[63] F.P. Glasser, L. Zhang, High Performance Cement Matrices Based on Calcium Sulfoaluminate-Belite Compositions, Cem. Concr. Res. 31 (2001) 1881-1886

[64] L. Zhang, F.P. Glasser, Hydration of Calcium Sulfoaluminate Cement at less than 24 Hours, Adv. Cem. Res., 14[4] (2002) 141-155

[65] V. Kasselouri, P. Tsakiridis, C. Malami, B. Georgali, C. Alexandridou, A Study on the Hydration Products of a Non-Expansive Sulfoaluminate Cement, Cem. Concr. Res., 25[8] (1995) 1726-1736

[66] D. Kalogridis, G. Kostogloudis, C. Ftikos, C. Malami, A Quantitative Study of Non Expansive Sulfoaluminate Cement on the Corrosion of Steel Reinforcement, Cem. Concr. Res. 30 (2000) 1731-1740

[67] I. Janotka, L. Krajci, A. Ray, S. Majumdar, The Hydration Phase and Pore Structure Formation in the Blends of Sulfoaluminate-Belite Cement with Portland Cement, Cem. Concr. Res. 33 (2003) 489-497

[68] I. Janotka, L. Krajci, An Experimental Study on the Upgrade of Sulfoaluminate-Belite Cement Systems by Blending with Portland Cement, Adv. Cem. Res. 11[1] (1999) 35-41

[68] O. Andac, F.P. Glasser, Pore Solution Composition of Calcium Sulfoaluminate Cement, Adv. Cem. Res. 11[1] (1999) 23-26

[69] L.C. Chow, Calcium Phosphate Cements : Chemistry, Properties and Applications, Mat. Res. Soc. Symp. Proc. 599 (2000) 27-37

[70] F.C.M. Driessens, Chemistry of Calcium Phosphate Cements, Proc. $4^{\text {th }}$ European Ceramic Conference, Riccione 2-6 October, Italy 8 (1995) 77-83 
[71] J. Lemaître, Biocéramiques et Biociments Résorbables pour le Comblement Osseux, in Traité des Matériaux, 19, Matériaux Emergents, C. Janot and B. Ilschner Ed., Presses Polytechniques et Universitaires Romandes, Lausanne, Switzerland (2001) 289-314

[72] J. Pera, J. Ambroise, Fiber Reinforced Magnesia Phosphate Cement Composites for Rapid Repair, Cem. Concr. Composites 20 (1998) 31-39

[73] S. Popovics, N. Rajendran, M. Penko, Rapid Hardening Cements for Repair of Concrete, ACI Materials J. 84[1] (1987) 64-73

[74] B. El Jazairi, The Properties of Hardened MPC Mortar and Concrete Relevant to the Requirements of Rapid Repair of Concrete Pavements, Concrete 21 (1987) 25-31

[75] S.S. Seehra, S. Gupta, S.S. Kumar, Rapid Setting Magnesium Phosphate Cement for Quick Repair of Concrete Pavements - Characterization and Durability Aspects, Cem. Concr. Res. 23[2] (1993) 254-266

[76] A.S. Wagh, J.C. Cunnana, D. Singh, D.T. Reed, S. Armstrong, W. Subhan, N. Chawla, Chemically Phosphate Ceramics for Radioactive and Mixed-Waste Solidification and Stabilization, Proc. Conference Technology and Programs for Radioactive Waste Management and Environmental Remediation, WM'93, Tucson, USA 2 (1997) 1613-1617

[77] E. Soudee, J. Pera, Mechanism of Setting Reaction in Magnesia-Phosphate Cements, Cem. Concr. Res. 30 (2000) 315-321

[78] H. Scheffé, Experiments with Mixtures, J. Roy. Soc. Stat. Soc. Ser. B 20 (1958) 344-360

[79] H.F.W Taylor, Cement Chemistry, Second Edition, Thomas Telford Publishing, London, GB (1997)

[80] G. Dreux, J. Festa, Nouveau Guide du Béton et de ses Constituants, $8^{\text {th }}$ edition, Eyrolles, Paris, France (1998) 
Table 1: Specifications for low-pH materials.

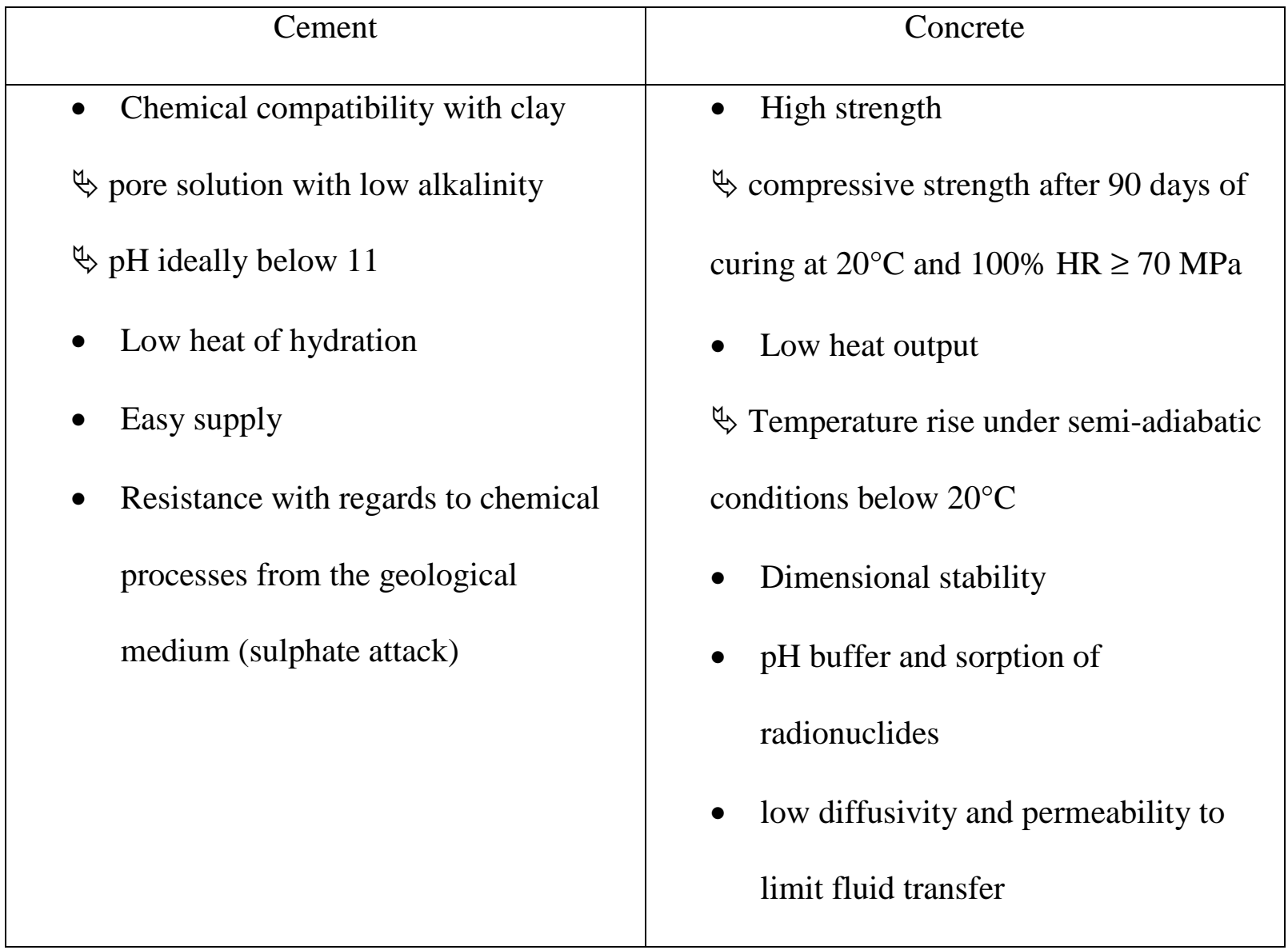


Table 2: Previously reported low $\mathrm{pH}$ concretes.

\begin{tabular}{|c|c|c|c|}
\hline Reference & $\begin{array}{c}\text { OSF Concrete } \\
{[51]}\end{array}$ & $\begin{array}{c}\text { LHHPC Concrete } \\
{[49]}\end{array}$ & $\begin{array}{c}\text { 36F Concrete } \\
{[50]}\end{array}$ \\
\hline $\begin{array}{l}\text { Blend composition } \\
(\%)\end{array}$ & $\begin{array}{l}\text { OPC }: 40 \\
\text { SF }: 20 \\
\text { FA }: 40\end{array}$ & $\begin{array}{l}\text { OPC }: 50 \\
\text { SF }: 50\end{array}$ & $\begin{array}{l}\text { OPC }: 83.3 \\
\text { SF }: 16.7\end{array}$ \\
\hline $\begin{array}{l}\text { OPC content } \\
\left(\mathrm{kg} / \mathrm{m}^{3}\right)\end{array}$ & 200 & 97 & 150 \\
\hline $\begin{array}{c}\text { Pozzolanic additions } \\
\left(\mathrm{kg} / \mathrm{m}^{3}\right)\end{array}$ & $\begin{array}{l}\text { FA : } 200 \\
\text { SF }: 100\end{array}$ & SF : 97 & SF : 30 \\
\hline $\begin{array}{c}\text { Cement content } \\
(\mathrm{OPC}+\text { additions }) \\
\left(\mathrm{kg} / \mathrm{m}^{3}\right)\end{array}$ & 500 & 194 & 180 \\
\hline W/OPC & 0.75 & 1 & 0.98 \\
\hline $\begin{array}{c}\mathrm{W} / \mathrm{C}(\mathrm{OPC}+ \\
\text { additions })\end{array}$ & 0.3 & 0.5 & 0.82 \\
\hline $\begin{array}{c}\text { Aggregates content } \\
\left(\mathrm{kg} / \mathrm{m}^{3}\right)\end{array}$ & 1656 & 1935 & 2005.5 \\
\hline $\begin{array}{c}\text { Sand / aggregates } \\
\left(\mathrm{kg} / \mathrm{m}^{3}\right)\end{array}$ & 1.208 & 0.861 & 1.900 \\
\hline $\begin{array}{l}\text { Quartzitic filler } \\
\left(\mathrm{kg} / \mathrm{m}^{3}\right)\end{array}$ & - & 194 & 200 \\
\hline $\begin{array}{l}\text { Plasticizer content } \\
\text { (cement weight \%) }\end{array}$ & 3 & 5.3 & 1.2 \\
\hline $\begin{array}{c}\text { Slump after mixing } \\
(\mathrm{mm})\end{array}$ & 72.5 & - & 450 \\
\hline $\begin{array}{c}\text { Temperature rise } \\
\text { (adiabatic conditions) }\end{array}$ & $50.2^{\circ} \mathrm{C}$ & $\approx 20^{\circ} \mathrm{C}$ & - \\
\hline $\begin{array}{c}\text { Compressive strength } \\
(\mathrm{MPa})\end{array}$ & $105.7(91 \mathrm{~d})$ & $\approx 80(90 \mathrm{~d})$ & $\begin{array}{c}54.6(91 \mathrm{~d}) \\
77.8(1 \mathrm{y})\end{array}$ \\
\hline $\begin{array}{l}\text { Total shrinkage } \\
(\mu \mathrm{m} / \mathrm{m})\end{array}$ & $-516(90 d)$ & - & $\approx-500(90 \mathrm{~d})$ \\
\hline $\begin{array}{c}\mathrm{pH} \text { of water } \\
\text { equilibrated with } \\
\text { crushed material }\end{array}$ & $\begin{array}{c}11 \\
(28 \mathrm{~d}-\text { Water / Solid } \\
=40 / 1)\end{array}$ & $\begin{array}{c}10.6 \\
(90 \mathrm{~d}-\text { Water / Solid } \\
=1 / 1)\end{array}$ & $\begin{array}{c}11.7 \\
(28 \mathrm{~d}-\text { Water / Solid } \\
=1.675 / 1)\end{array}$ \\
\hline
\end{tabular}


Table 3: Characteristics of the blends components.

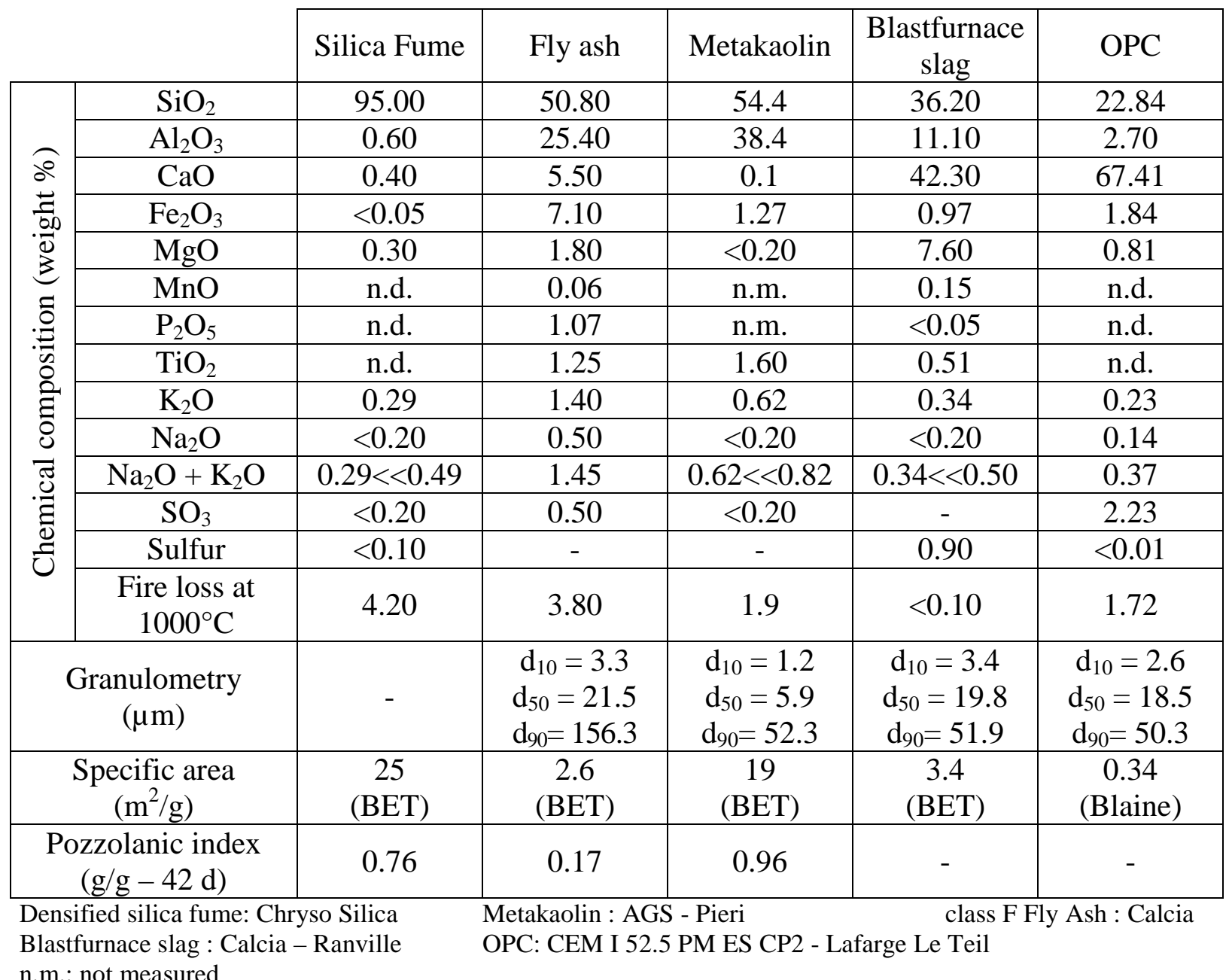


Table 4: $\mathrm{pH}$ evolution of the suspensions prepared from binary blends.

\begin{tabular}{|c|c|c|c|c|}
\hline \multirow{2}{*}{$\begin{array}{c}\text { Blend } \\
\text { composition }\end{array}$} & \multicolumn{4}{|c|}{$\mathrm{pH}$} \\
\hline $\begin{array}{c}\text { OPC 40\% } \\
\text { SF 60\% }\end{array}$ & 10.4 & $29 \mathrm{~d}$ & $40 \mathrm{~d}$ & $57 \mathrm{~d}$ \\
\hline $\begin{array}{c}\text { OPC 50\% } \\
\text { SF 50\% }\end{array}$ & 10.5 & 10.7 & 10.4 & 10.3 \\
\hline $\begin{array}{c}\text { OPC 60\% } \\
\text { SF 40\% }\end{array}$ & 11.4 & 11.1 & 10.5 & 10.3 \\
\hline $\begin{array}{c}\text { OPC 70\% } \\
\text { SF 30\% }\end{array}$ & 12.2 & 12.2 & 12.1 & 12.9 \\
\hline $\begin{array}{c}\text { OPC 40\% } \\
\text { MK 60\% }\end{array}$ & 11.9 & 12.0 & 12.1 & 12.1 \\
\hline $\begin{array}{c}\text { OPC 50\% } \\
\text { MK 50\% }\end{array}$ & 12.1 & 12.1 & 12.2 & 12.1 \\
\hline $\begin{array}{c}\text { OPC 60\% } \\
\text { MK 40\% }\end{array}$ & 12.2 & 12.2 & 12.3 & 12.2 \\
\hline $\begin{array}{c}\text { OPC 70\% } \\
\text { MK 30\% }\end{array}$ & 12.5 & 12.5 & 12.5 & 12.5 \\
\hline
\end{tabular}


Table 5: Measured responses.

\begin{tabular}{|c|c|c|c|c|c|c|c|c|c|c|}
\hline \multirow{2}{*}{\multicolumn{2}{|c|}{$\mathrm{pH}$ at }} & \multicolumn{3}{|c|}{ OPC / SF / FA blends } & \multicolumn{3}{|c|}{ OPC / MK / FA blends } & \multicolumn{3}{|c|}{ OPC / SF / BFS blends } \\
\hline & & $17 \mathrm{~d}$ & $29 \mathrm{~d}$ & $73 \mathrm{~d}$ & $29 \mathrm{~d}$ & $40 \mathrm{~d}$ & $59 \mathrm{~d}$ & $17 \mathrm{~d}$ & $40 \mathrm{~d}$ & $112 \mathrm{~d}$ \\
\hline \multirow{12}{*}{ 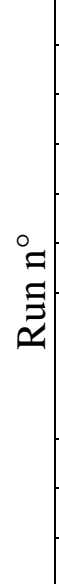 } & 1 & 12.34 & 12.18 & 12.14 & 12.36 & 12.40 & 12.44 & 12.70 & 12.25 & 12.26 \\
\hline & 2 & 11.27 & 11.14 & 10.99 & 11.70 & 11.63 & 11.59 & 10.88 & 10.24 & 10.14 \\
\hline & 3 & 11.99 & 11.67 & 11.51 & 11.83 & 11.84 & 11.78 & 12.24 & 11.95 & 11.70 \\
\hline & 4 & 11.33 & 11.10 & 10.98 & 11.85 & 11.96 & 11.96 & 11.88 & 11.18 & 10.72 \\
\hline & 5 & 12.04 & 1157 & 11.35 & 12.07 & 11.97 & 11.95 & 12.41 & 12.18 & 11.96 \\
\hline & 6 & 11.29 & 11.13 & 11.00 & 11.76 & 11.73 & 11.69 & 11.66 & 10.81 & 10.47 \\
\hline & & 11.53 & 11.25 & 11.04 & 11.92 & 11.96 & 11.92 & 12.01 & 11.45 & 11.15 \\
\hline & 7 & 11.45 & 11.18 & 10.98 & 11.93 & 11.94 & 11.90 & 12.03 & 11.50 & 11.12 \\
\hline & & 11.43 & 11.16 & 10.99 & 12.05 & 12.08 & 11.95 & 12.03 & 11.51 & 11.17 \\
\hline & 8 & 11.94 & 11.58 & 11.31 & 12.20 & 12.14 & 12.05 & 12.35 & 12.03 & 11.87 \\
\hline & 9 & 11.15 & 10.99 & 10.87 & 11.74 & 11.80 & 11.76 & 11.41 & 10.66 & 10.37 \\
\hline & 10 & 11.79 & 11.47 & 11.25 & 11.94 & 11.94 & 11.94 & 12.16 & 11.84 & 11.48 \\
\hline
\end{tabular}


Table 6 : Estimated model coefficients.

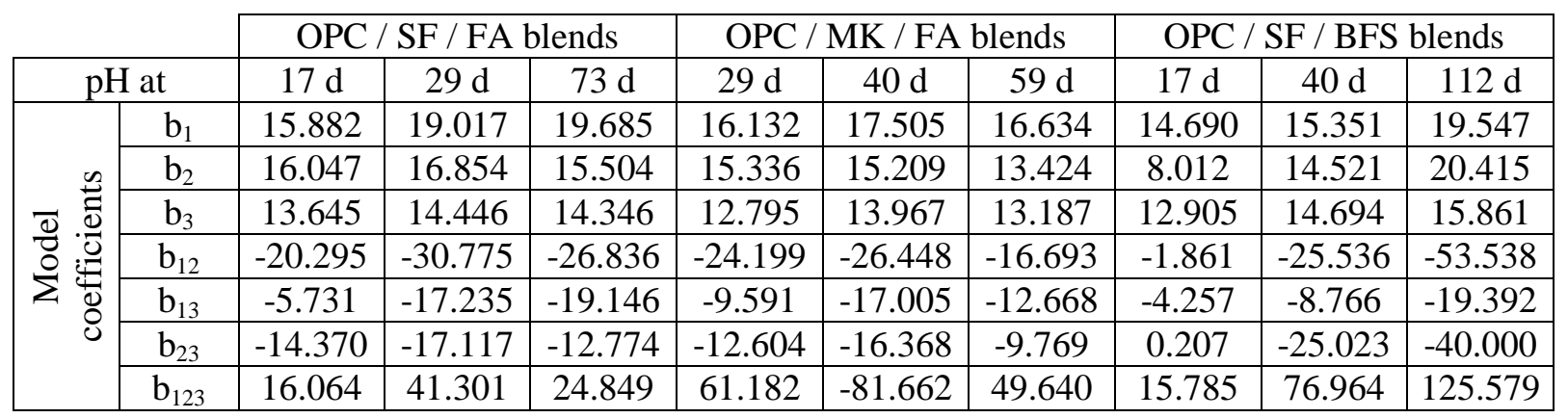


Table 7: Properties of elaborated mortars.

\begin{tabular}{|c|c|c|c|c|c|}
\hline & Blend \#1 & Blend \#2 & Blend \#3 & Blend \#4 & $\begin{array}{c}\text { Blend \#5 } \\
\text { (probe) }\end{array}$ \\
\hline Blend composition & $\begin{array}{l}\text { CEM I 37.5\% } \\
\text { SF 32.5\% } \\
\text { FA 30 } \%\end{array}$ & $\begin{array}{l}\text { CEM I } 50 \% \\
\text { SF } 50 \%\end{array}$ & $\begin{array}{l}\text { CEM I } 40 \% \\
\text { SF } 20 \% \\
\text { FA } 40 \%\end{array}$ & $\begin{array}{l}\text { CEM I } 83.3 \% \\
\text { SF } 16.7 \%\end{array}$ & CEM I $100 \%$ \\
\hline $\begin{array}{c}\text { Plasticizer content to get a } \\
\text { workability comparable to } \\
\text { that of the probe } \\
\text { ( / weight of cement) }\end{array}$ & $1.1 \%$ & $2.6 \%$ & $0.5 \%$ & $0.3 \%$ & $0 \%$ \\
\hline Bleeding at $24 \mathrm{~h}$ & nul & nul & nul & nul & nul \\
\hline Vicat setting & $\begin{array}{l}\text { beginning: } 6 \mathrm{~h} \\
\text { end : } 7 \mathrm{~h}\end{array}$ & $\begin{array}{l}\text { beginning : } 4 \mathrm{~h} \\
\text { end }: 5 \mathrm{~h}\end{array}$ & $\begin{array}{l}\text { beginning: } 7 \mathrm{~h} \\
\text { end }: 8 \mathrm{~h}\end{array}$ & $\begin{array}{l}\text { beginning: } 3 \mathrm{~h} \\
\text { end : } 5 \mathrm{~h}\end{array}$ & $\begin{array}{l}\text { beginning: } 3 \mathrm{~h} \\
\text { end }: 5 \mathrm{~h}\end{array}$ \\
\hline $\begin{array}{c}\text { Temperature rise }\left({ }^{\circ} \mathrm{C}\right) \\
\text { (Langavant calorimetry) }\end{array}$ & 13.1 & 20.0 & 14.7 & 23.0 & 23.4 \\
\hline $\begin{array}{c}\text { Total porosity } \\
\text { (curing under water) }\end{array}$ & $\begin{array}{l}23.1 \%(3 \mathrm{~m}) \\
22.5 \%(6 \mathrm{~m}) \\
20.0 \%(1 \mathrm{y})\end{array}$ & $\begin{array}{l}18.0 \%(3 \mathrm{~m}) \\
15.5 \%(6 \mathrm{~m}) \\
14.3 \%(1 \mathrm{y})\end{array}$ & $\begin{array}{l}24.1 \%(3 \mathrm{~m}) \\
23.9 \%(6 \mathrm{~m}) \\
22.0 \%(6 \mathrm{~m})\end{array}$ & $\begin{array}{l}- \\
- \\
-\end{array}$ & $\begin{array}{l}13.9 \%(3 \mathrm{~m}) \\
13.8 \%(6 \mathrm{~m}) \\
14.1 \%(1 \mathrm{y})\end{array}$ \\
\hline $\begin{array}{c}\text { Porosity below } 20 \mathrm{~nm}(\% \text { of } \\
\text { total porosity) } \\
\text { (1 year of curing under } \\
\text { water) }\end{array}$ & $67.6 \%$ & $75.5 \%$ & $57.9 \%$ & - & $38.9 \%$ \\
\hline $\begin{array}{l}\text { Dimensional variations after } \\
\text { one year of curing }(\mu \mathrm{m} / \mathrm{m})\end{array}$ & $\begin{array}{c}\text { Air : }-1042 \\
\text { Bag : }-474 \\
\text { Water }:+324 \\
\end{array}$ & $\begin{array}{c}\text { Air : }-1171 \\
\text { Bag : }-591 \\
\text { Water }:+349 \\
\end{array}$ & $\begin{array}{c}\text { Air : }-923 \\
\text { Bag : }-437 \\
\text { Water : }+293 \\
\end{array}$ & $\begin{array}{c}\text { Air : }-824 \\
\text { Bag : }-337 \\
\text { Water : }+225 \\
\end{array}$ & $\begin{array}{c}\text { Air : }-660 \\
\text { Bag : }-323 \\
\text { Water : }+199 \\
\end{array}$ \\
\hline $\begin{array}{l}\text { Compressive strength after } \\
\text { one year of curing (MPa) }\end{array}$ & $\begin{array}{c}\text { Air }: 28.3 \\
\text { Bag : } 46.7 \\
\text { Water : } 60.3 \\
\end{array}$ & $\begin{array}{c}\text { Air : } 61.3 \\
\text { Bag : } 91.8 \\
\text { Water }: 89.0\end{array}$ & $\begin{array}{c}\text { Air : } 21.1 \\
\text { Bag : } 44.3 \\
\text { Water : } 51.7\end{array}$ & $\begin{array}{c}\text { Air : } 32.2 \\
\text { Bag : } 51.5 \\
\text { Water : } 55.2 \\
\end{array}$ & $\begin{array}{c}\text { Air : } 39.8 \\
\text { Bag : } 62.6 \\
\text { Water : } 65.4\end{array}$ \\
\hline $\begin{array}{c}\text { Portlandite content after one } \\
\text { year of curing in air-tight } \\
\text { bag }\end{array}$ & $\begin{array}{l}\text { Non detectable } \\
\text { by TDA }\end{array}$ & $\begin{array}{l}\text { Non detectable } \\
\text { by TDA }\end{array}$ & traces & $1.78 \%$ & $5.50 \%$ \\
\hline $\begin{array}{c}\mathrm{pH} \text { of suspension prepared } \\
\text { from crushed mortar after } \\
\text { one year of curing in air- } \\
\text { tight bag (Liquid/Solid = } 9 \\
\mathrm{~mL} / \mathrm{g})\end{array}$ & 11.3 & 11.3 & 11.5 & 12.5 & 12.6 \\
\hline
\end{tabular}


Table 8: Concrete recipes and properties of resulting materials.

\begin{tabular}{|c|c|c|c|c|}
\hline \multirow{4}{*}{ 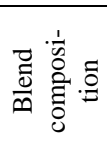 } & Reference & 1 & 2 ' & 5 \\
\hline & $\%$ CEM I & 37.5 & 60 & 100 \\
\hline & $\% \mathrm{SF}$ & 32.5 & 40 & 0 \\
\hline & $\% \mathrm{FA}$ & 30 & 0 & \\
\hline \multirow{5}{*}{ 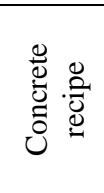 } & Cement & \multicolumn{3}{|c|}{$400 \mathrm{~kg} / \mathrm{m}^{3}$} \\
\hline & Sand 0-4 & \multirow{2}{*}{\multicolumn{3}{|c|}{$\frac{710 \mathrm{~kg} / \mathrm{m}^{3}}{1158 \mathrm{~kg} / \mathrm{m}^{3}}$}} \\
\hline & Aggregates 4-15 & \multicolumn{2}{|r|}{$1158 \mathrm{~kg} / \mathrm{m}^{3}$} & \\
\hline & Water & $160 \mathrm{~kg} / \mathrm{m}^{3}$ & $160 \mathrm{~kg} / \mathrm{m}^{3}$ & $132 \mathrm{~kg} / \mathrm{m}^{3}$ \\
\hline & Superplasticizer & $4 \mathrm{~kg} / \mathrm{m}^{3}$ & $6 \mathrm{~kg} / \mathrm{m}^{3}$ & $3 \mathrm{~kg} / \mathrm{m}^{3}$ \\
\hline \multirow{5}{*}{ 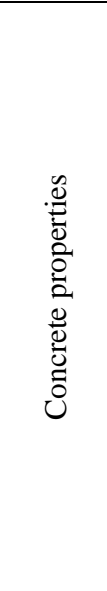 } & $\begin{array}{l}\text { Slump } \\
(\mathrm{mm})\end{array}$ & 100 & 140 & 145 \\
\hline & $\begin{array}{c}\text { Temperature rise } \\
\left({ }^{\circ} \mathrm{C}\right)\end{array}$ & 14.2 & 20.6 & 23.3 \\
\hline & $\begin{array}{l}\text { Heat of hydration } \\
(\mathrm{J} / \mathrm{g} \text { of binder }-60 \mathrm{~h})\end{array}$ & 184 & 248 & 273 \\
\hline & $\begin{array}{c}\text { Compressive } \\
\text { strength (MPa) }\end{array}$ & $\begin{array}{c}28 \mathrm{~d}-\text { water }: 55.0 \\
90 \mathrm{~d}-\text { water }: 69.0 \pm 3.7 \\
90 \mathrm{~d}-\text { bag }: 66.6 \pm 0.7 \\
90 \mathrm{~d}-\text { air }: 48.1 \pm 0.9\end{array}$ & $\begin{array}{c}28 \mathrm{~d} \text { - water : } 77.0 \\
90 \mathrm{~d}-\text { water }: 82.0 \pm 2.0 \\
90 \mathrm{~d}-\text { bag }: 78.4 \pm 3.0 \\
90 \mathrm{~d}-\text { air }: 67.5 \pm 0.9\end{array}$ & $28 \mathrm{~d}$ - water : 84.0 \\
\hline & $\begin{array}{c}\text { Dimensional } \\
\text { variations }(\mu \mathrm{m} / \mathrm{m})\end{array}$ & $\begin{array}{c}28 \mathrm{~d}-\text { water }:+110 \\
90 \mathrm{~d}-\text { water }:+130 \\
28 \mathrm{~d}-\text { bag }:-158 \\
90 \mathrm{~d}-\text { bag : }-265 \\
28 \mathrm{~d}-\text { air }:-265 \\
90 \mathrm{~d}-\text { air }:-350\end{array}$ & $\begin{array}{c}28 \mathrm{~d}-\text { water }:+75 \\
90 \mathrm{~d}-\text { water : }+97 \\
28 \mathrm{~d}-\text { bag : }-130 \\
90 \mathrm{~d}-\text { bag : }-243 \\
28 \mathrm{~d} \text { - air : - } 260 \\
90 \mathrm{~d} \text { - air : }-352\end{array}$ & - \\
\hline
\end{tabular}

Temperature rise was measured on equivalent mortars in Langavant calorimeters.

Compressive strength at $90 \mathrm{~d}$ was measured on $7 \times 7 \times 28 \mathrm{~cm}$ samples. The results were corrected so as to obtain estimates of the strength of $11 \times 22 \mathrm{~cm}$ samples. 
Figure 1: Investigated concept of disposal for medium level wastes [1].

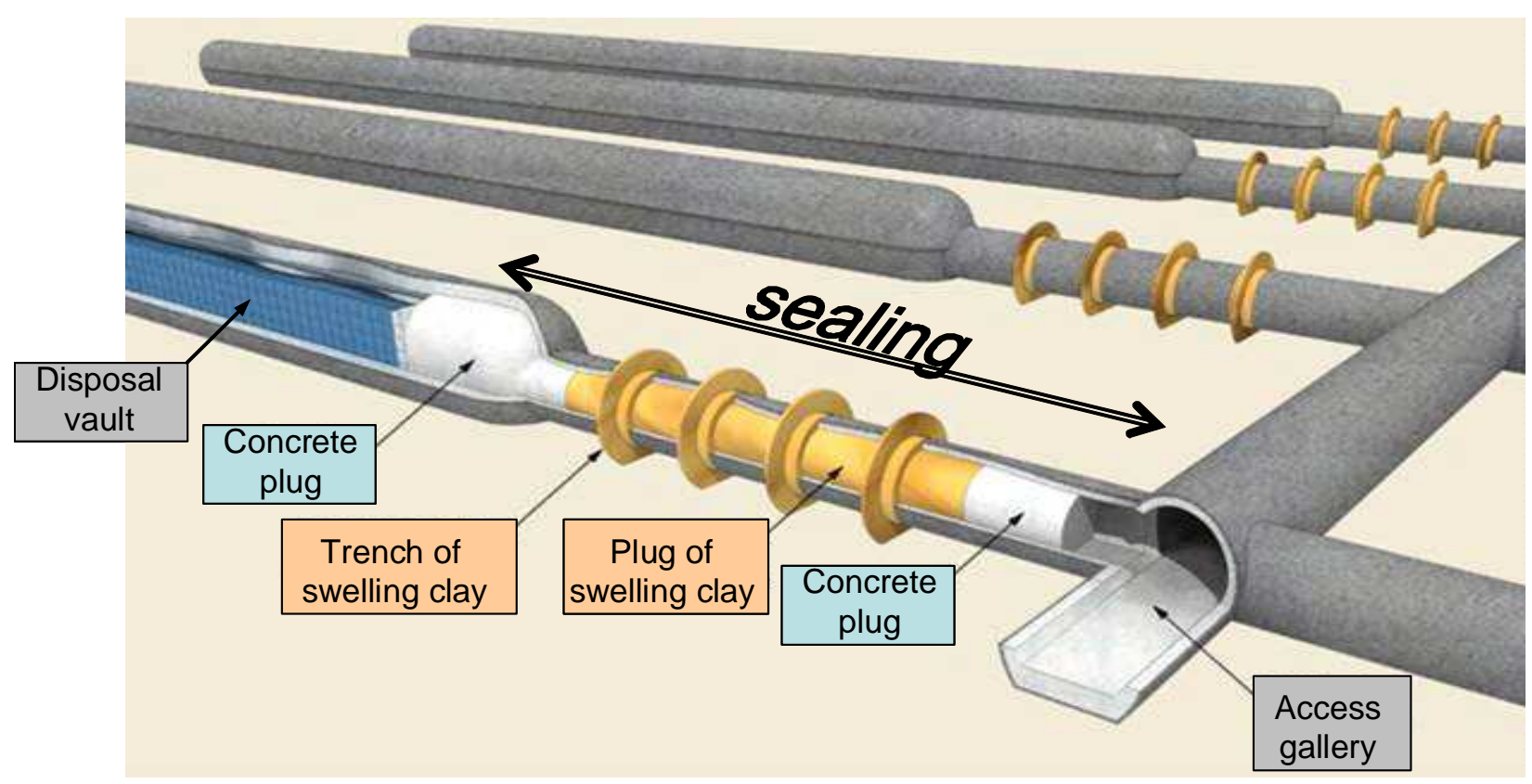


Figure 2: Schematic evolution of pore solution $\mathrm{pH}$ during leaching by pure water of sulphate resistant Portland cement paste $[6,7]$.

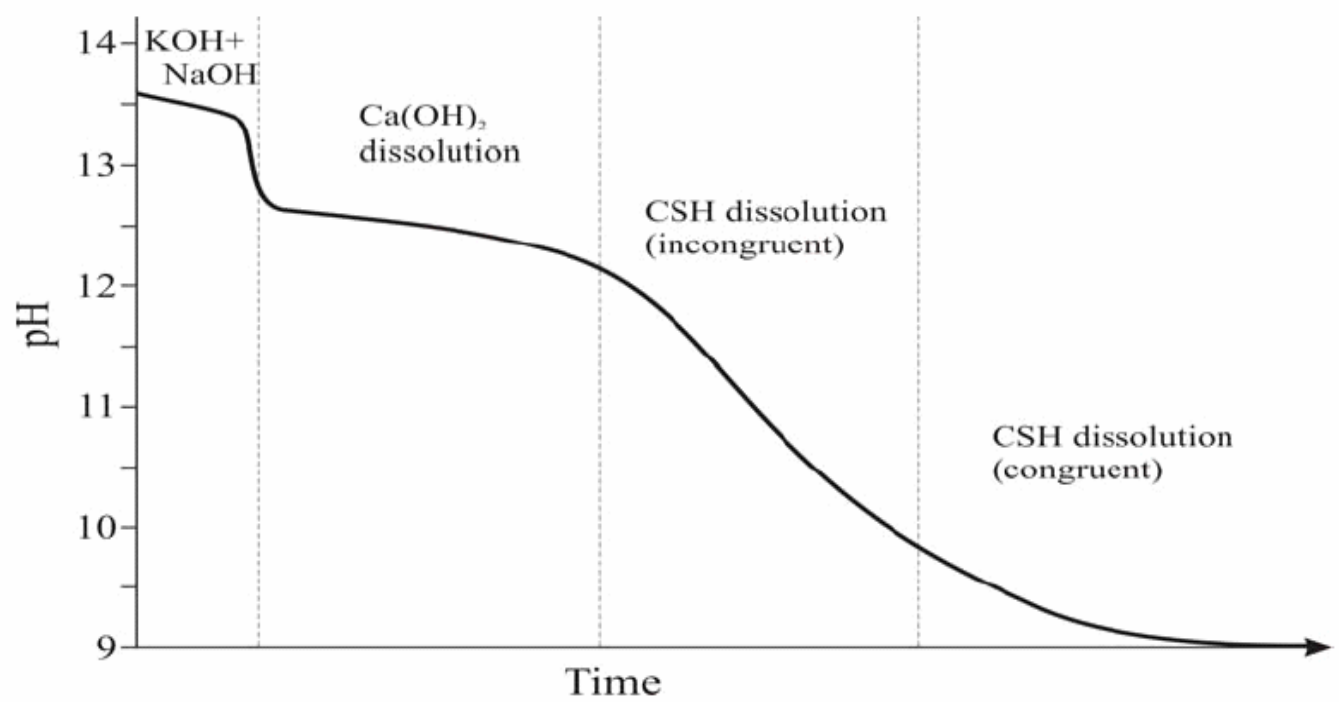


Figure 3: Equilibrium pH of binary blends consisting of OPC and SF or MK.

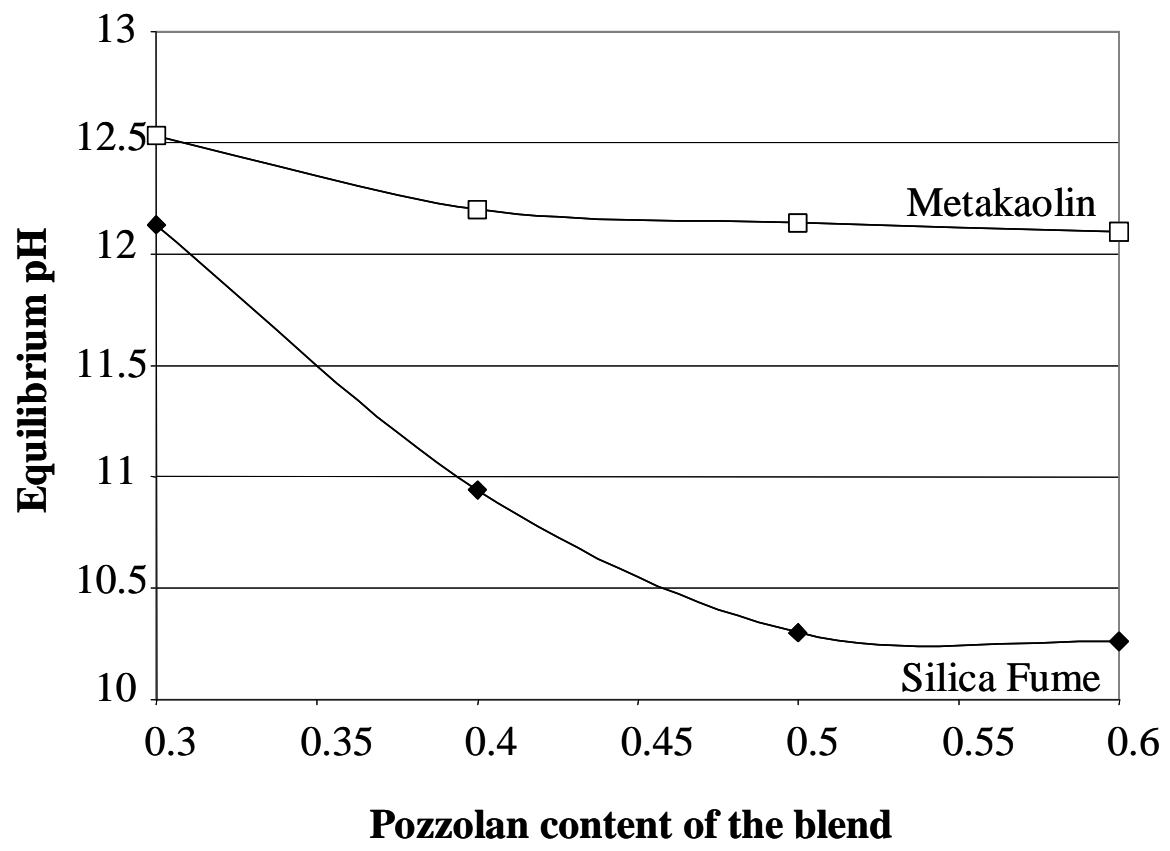


Figure 4 : Experimental domain and selected design.

\begin{tabular}{|c|c|c|c|}
\hline OPC fract & tion & & $\mathrm{X}_{1}$ \\
\hline SF or MK & K fractio & & $\mathrm{X}_{2}$ \\
\hline FA or BFS & $S$ fracti & on & $\mathrm{X}_{3}$ \\
\hline$\underline{N^{\circ} \operatorname{Exp}}$ & $p \quad X_{1}$ & $\underline{X}_{2}$ & $\mathrm{X}_{3}$ \\
\hline 1 & 0.5500 & 0.1500 & 0.3000 \\
\hline 2 & 0.2000 & 0.5000 & 0.3000 \\
\hline 3 & 0.2000 & 0.1500 & 0.6500 \\
\hline 4 & 0.3750 & 0.3250 & 0.3000 \\
\hline 5 & 0.3750 & 0.1500 & 0.4750 \\
\hline 6 & 0.2000 & 0.3250 & 0.4750 \\
\hline 7 & 0.3167 & 0.2667 & 0.4167 \\
\hline 8 & 0.4333 & 0.2083 & 0.3583 \\
\hline 9 & 0.2583 & 0.3833 & 0.3583 \\
\hline 10 & 02583 & مـ & 05333 \\
\hline
\end{tabular}

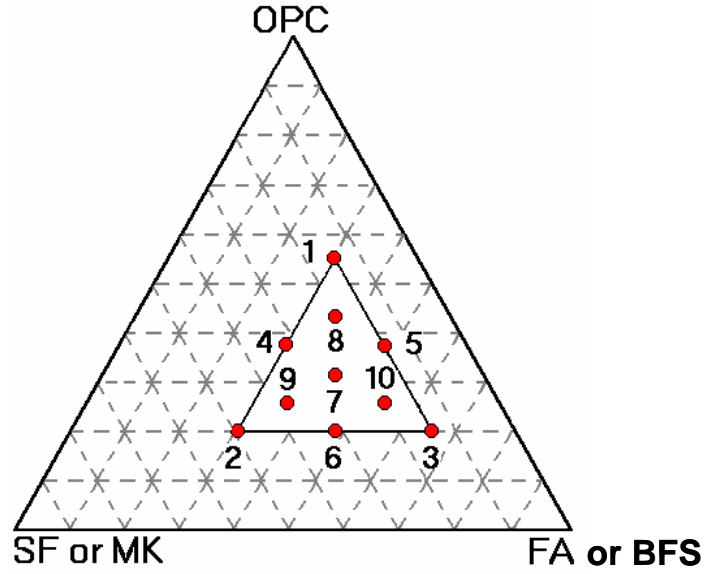


Figure 5: Evolution of pH contour plots for OPC / SF / FA, OPC / MK / FA and OPC / SF /

BFS blends.
A: OPC $55 \%$ - SF or MK $15 \%$ - FA or BFS $30 \%$
B: OPC $20 \%-$ SF or MK $50 \%$ - FA or BFS $30 \%$
C: OPC $20 \%$ - SF or MK $15 \%$ - FA or BFS $65 \%$

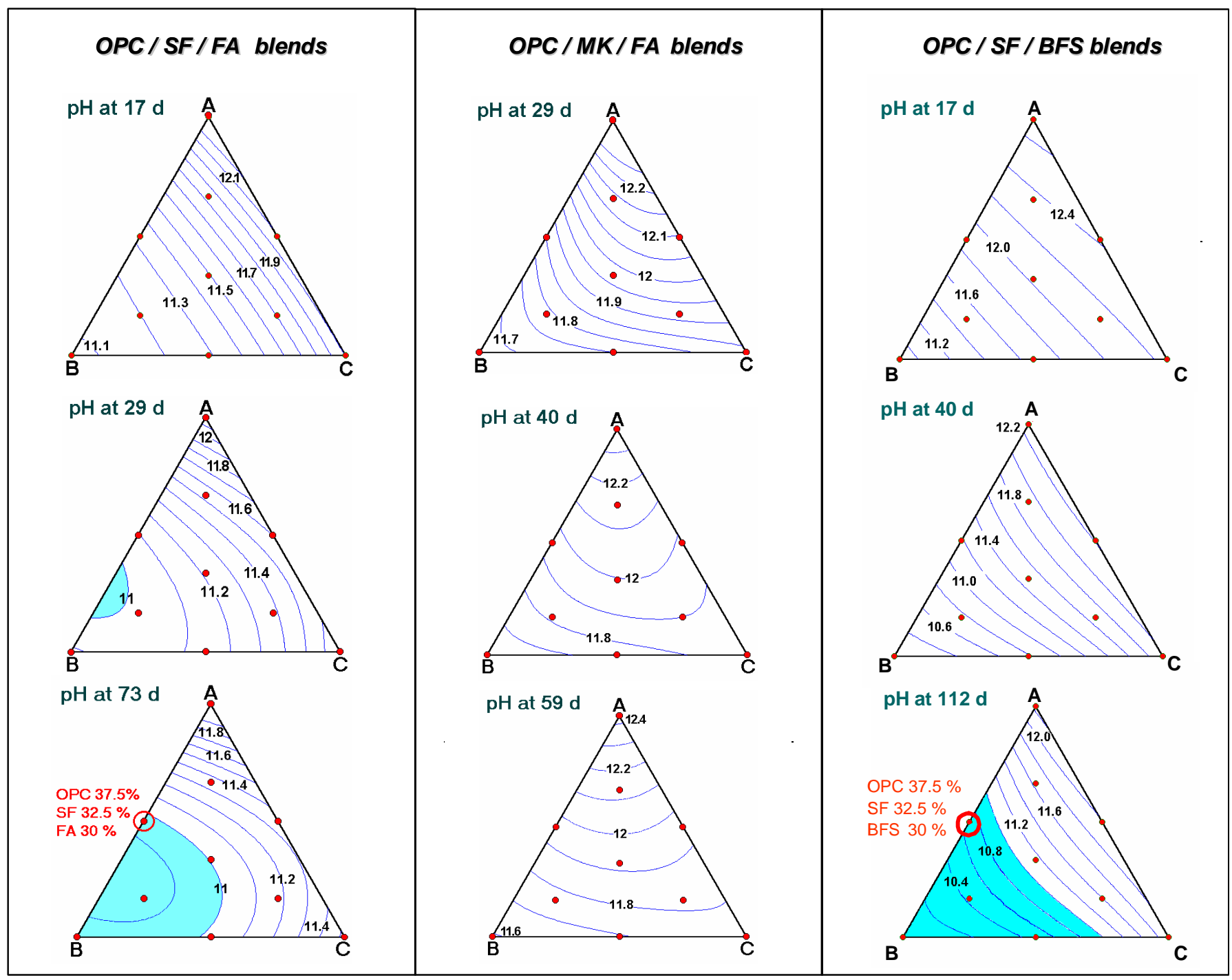


Figure 6: Correlation between silica content in the binder and equilibrium $\mathrm{pH}$.

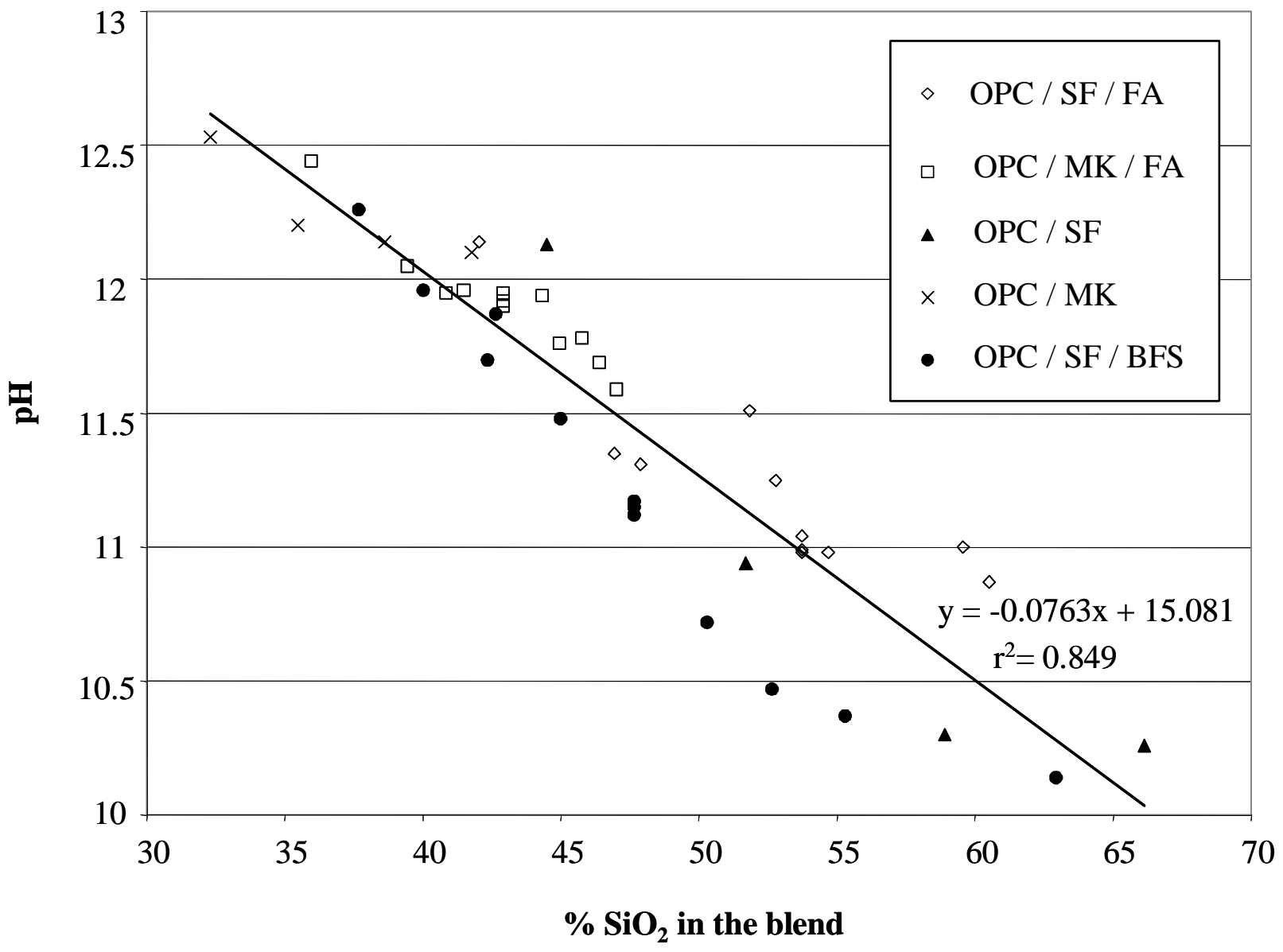


Figure 7: Investigated mortar compositions.

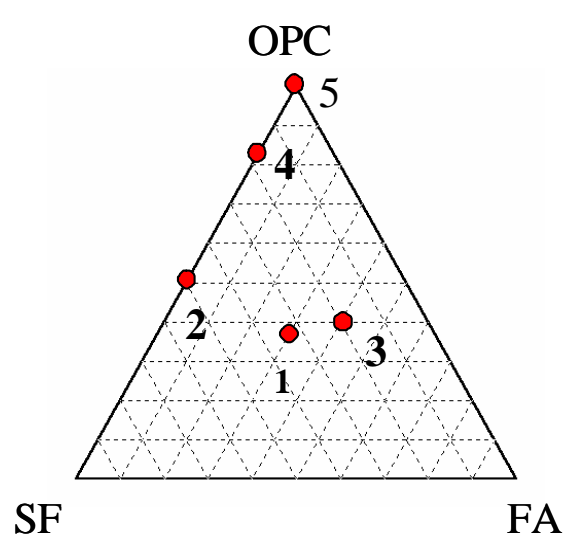

\section{$\underline{\text { Blend compositions }}$}

1: OPC $37.5 \%$ - SF $32.5 \%$ - FA $30 \%$

2: OPC 50\% - SF 50\% [49]

3: OPC $40 \%$ - SF $20 \%$ - FA 40\% [51]

4: OPC $83.3 \%$ - SF $16.7 \%$ [50]

5: OPC $100 \%$

Mortars: $\mathrm{W} / \mathrm{C}=0.5$, Sand $/$ Cement $=3$ 
Figure 8: Dependence of the plasticizer content (expressed as cement weight \%) on the silica fume content of the blend.

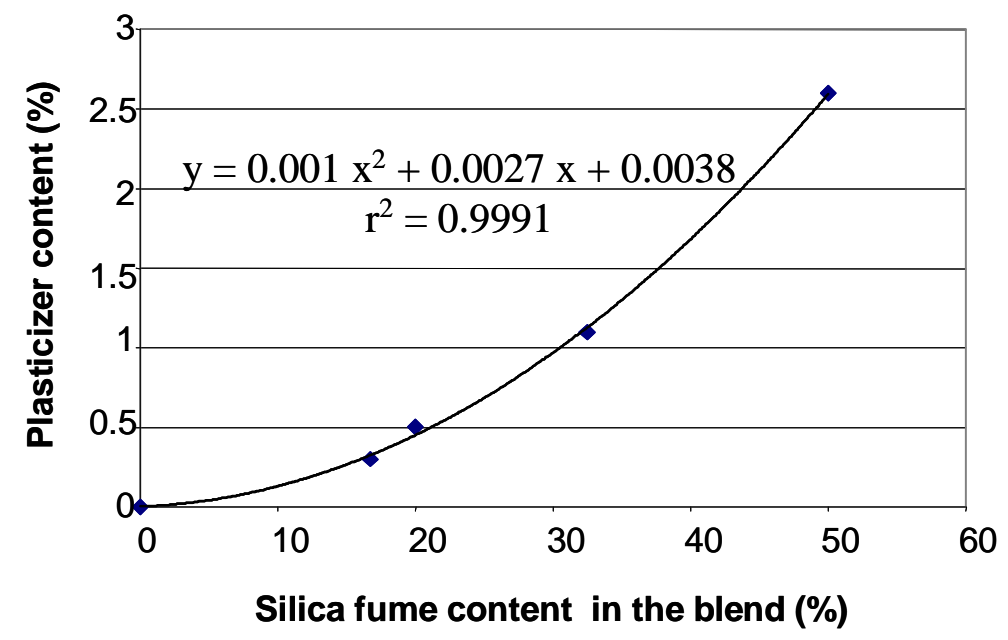


Figure 9: Shrinkage or swelling of $4 \times 4 \times 16 \mathrm{~cm}$ specimens cured at room temperature in airtight bag, in air or under water.

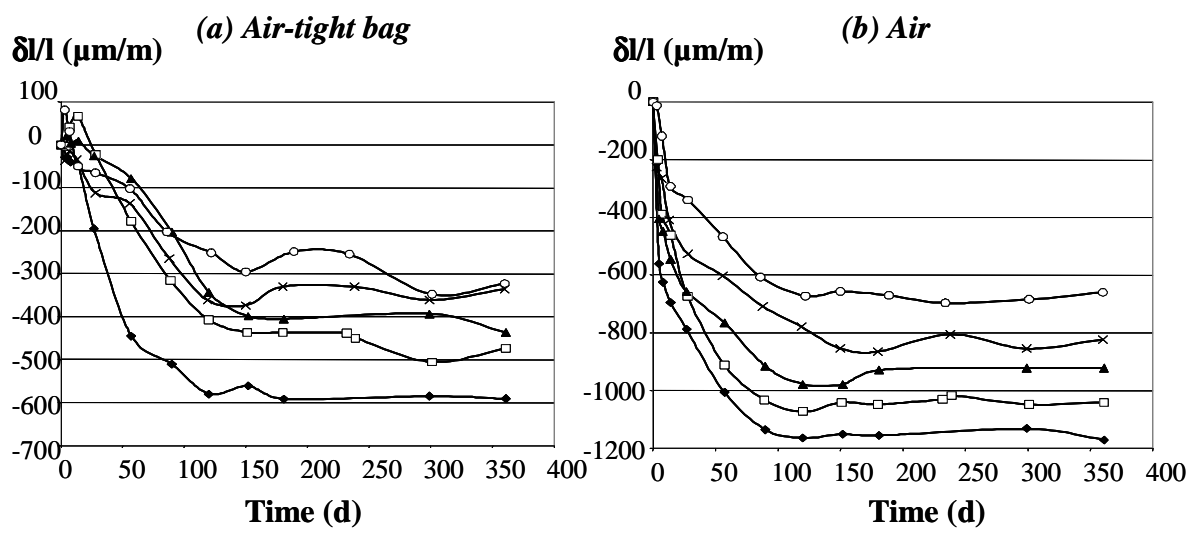

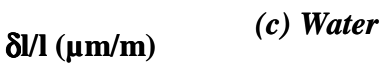

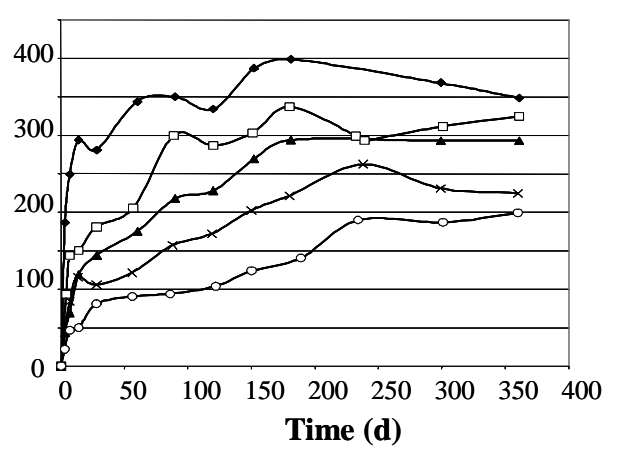

Mortar $\neg-1 \multimap 2 \dashv 3 \multimap 4 \rightarrow 5$ 
Figure 10: Compressive strength of $4 \times 4 \times 16 \mathrm{~cm}$ specimens cured at room temperature in airtight bag, in air or under water.
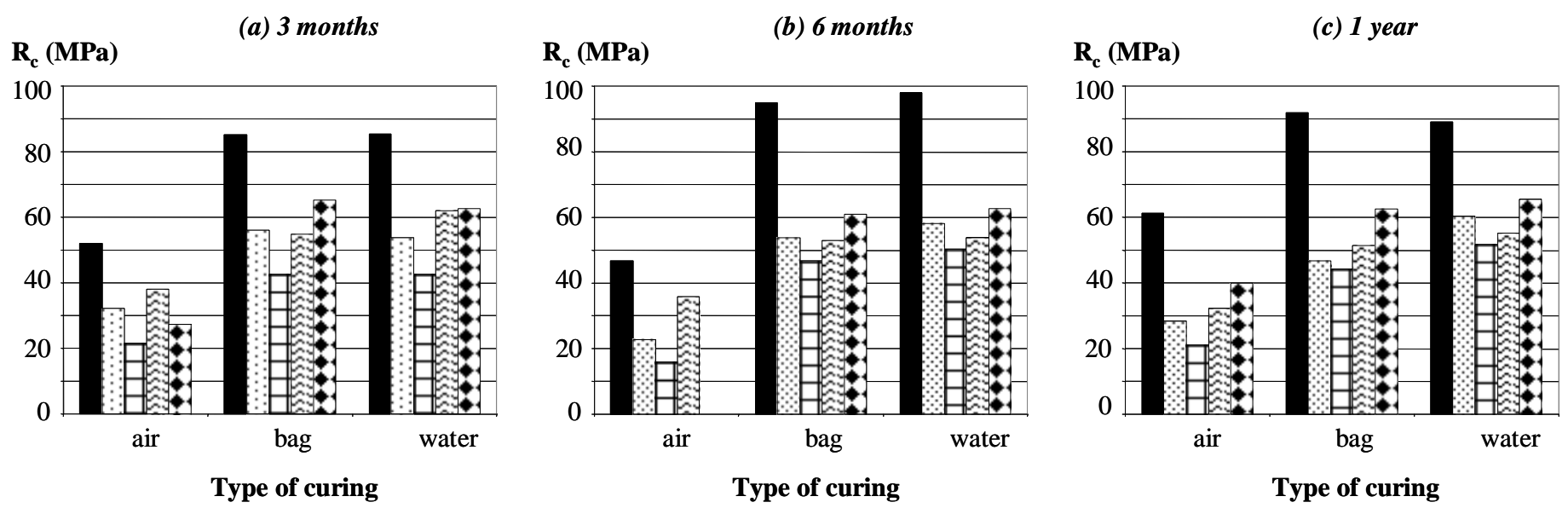

$\begin{array}{llllllll}\text { Mortar } & 1 & \square & \text { 耳 } & 3 & \text { 口 } & 4 & \end{array}$

